Review

\title{
Sources, Mobility, Reactivity, and Remediation of Heavy Metal(loid) Pollution: A Review
}

\author{
Remedios Martínez-Guijarro ${ }^{1,{ }^{+},{ }^{*}, \text { María Paches }}{ }^{2,}{ }^{\dagger}$, Inmaculada Romero ${ }^{1}$, Daniel Aguado ${ }^{2}$
}

1. EASE-Instituto Universitario de Investigación de Ingeniería del Agua y Medio Ambiente (IIAMA), Universitat Politècnica de València, Camí de Vera s/n, 46022 Valencia, Spain; E-Mails: mmarting@hma.upv.es; inrogi@dihma.upv.es

2. CALAGUA-Unidad Mixta UV-UPV, Instituto Universitario de Investigación de Ingeniería del Agua y Medio Ambiente (IIAMA), Universitat Politècnica de València, Camí de Vera s/n, 46022 Valencia, Spain; E-Mails: mapacgi@upvnet.upv.es; daaggar@hma.upv.es

+ These authors contributed equally to this work.

* Correspondence: Remedios Martínez-Guijarro; E-Mail: mmarting@hma.upv.es

Academic Editor: Giovanni DalCorso

Special Issue: Metal Pollution in the Environment

Adv Environ Eng Res

2021, volume 2, issue 4

doi:10.21926/aeer.2104033
Received: October 08, 2021

Accepted: November 28, 2021

Published: December 15,2021

\begin{abstract}
Heavy metal(loid)s are a group of elements present commonly in the environment, including $\mathrm{Cr}, \mathrm{Ni}, \mathrm{Cu}, \mathrm{Zn}, \mathrm{Cd}, \mathrm{Hg}, \mathrm{Pb}$, and As elements, among others. While these elements could have their origins in natural sources, anthropogenic activities, such as mining, agriculture, industry, etc., are also responsible for enhancing the concentration of these elements in the ecosystems up to undesirable levels. A few of these metal(loid)s serve as necessary micronutrients for life, while the others are extremely harmful and might affect the entire trophic chain upon entering the natural ecosystems due to their mobility and toxicity characteristics. Most of these heavy metal(loid) pollutants are already recognized for their harmful effects; nevertheless, their environmental control encounters obstruction due to various factors. In this context, the present report details the key points regarding the anthropogenic sources of
\end{abstract}

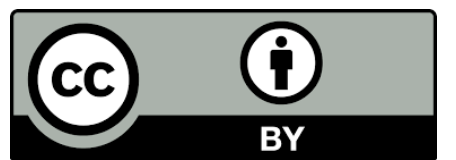

(C) 2021 by the author. This is an open access article distributed under the conditions of the Creative Commons by Attribution License, which permits unrestricted use, distribution, and reproduction in any medium or format, provided the original work is correctly cited. 
heavy metal(loid) pollution, which are increasing rapidly with time due to the emerging industry practices and processes, the elements causing this kind of pollution, and the physicochemical processes of these elements occurring in the environment-air interface, soil, and water-air interface. These elements exert a severe impact on the environment, which could be mitigated through the development and application of various remediation techniques. Therefore, the present report concludes with a final discussion on the various remediation treatments currently available for reducing the heavy metal(loid) contamination level in both water and soil.

\section{Keywords}

Heavy metal(loid)s; pollution; anthropogenic sources; remediation techniques; environmental impact

\section{Introduction}

Heavy metals and metalloids attract the interest of the current scientific community due to their toxic effects and their persistence in the environment [1]. The heavy metals, such as mercury $(\mathrm{Hg})$, lead $(\mathrm{Pb})$, cadmium ( $\mathrm{Cd}$ ), nickel (Ni), chromium ( $\mathrm{Cr}$ ), etc., and metalloids such as arsenic (As), cause a huge threat to the environment due to their non-biodegradable nature and their ability to bioaccumulate [2].

The natural source of these elements is the minerals present in the Earth's crust. Human activities, such as agricultural, industrial, and mining activities, have, however, led to a significant increase in the concentrations of heavy metals and metalloids in all kinds of environments (including terrestrial, aquatic, and atmospheric ecosystems) and/or the modification of the physicochemical status of these elements by increasing their toxicity. Therefore recognizing the origin, natural or anthropic, of the heavy metals and metalloids present in the environment is a key factor for managing the "actions" to reduce or minimize the environmental levels of these pollutants. Moreover, it is also important to determine the chemical characteristics of these elements in different environmental compartments (water, soil, and air) as the toxicity, mobility, and bioavailability of these pollutants are determined by their component chemical species.

Once these elements reach the natural ecosystems, they could occur in the form of free ions (metal hydroxides) as an organic or inorganic metal(loid) complex or in association with colloidal material. Metal(loid)s may be present in both dissolved and suspended particle forms in the aquatic systems or might be adsorbed onto solid elements that would ultimately settle into the sediments or transform into volatile forms that would spread all around along with the prevailing winds.

Upon entering the food chain, these heavy metals and other elements affect the cellular organelles and components of living organisms, including the cell membrane, mitochondria, lysosomes, endoplasmic reticulum, nuclei, and certain enzymes involved in metabolic, detoxification, and damage repair processes [3]. These elements may disrupt the metabolic activities of living organisms. For instance, since arsenic is similar to phosphorous, the former interferes with the metabolic processes of phosphate, which is widespread in the biosphere. Cd is the element that is most readily absorbed by organisms directly from water, where it is present in 
its free ionic form of $\mathrm{Cd}(\mathrm{II})$. Since $\mathrm{Cd}$ is not an essential element, there is no homeostatic control process for it in the body of organisms, which implies that the $\mathrm{Cd}$ element may accumulate inside the organisms. $\mathrm{Cd}$ is recognized for having a high affinity for $\mathrm{Ca}$ binding sites, which is assumed to be one of the main reasons causing $\mathrm{Cd}$ accumulation in tissues [2]. Moreover, at extremely low concentrations, $\mathrm{Cd}$ exerts a small influence on both replicative and repair DNA syntheses [4]).

It is noteworthy that a few of these elements, such as cobalt (Co), copper ( $\mathrm{Cu}$ ), chromium ( $\mathrm{Cr}$ ), iron (Fe), nickel ( $\mathrm{Ni})$, zinc $(\mathrm{Zn})$, etc., are essential micronutrients for plants or animals, and their deficiency leads to different diseases or syndromes. On the other hand, an excess of these compounds may also cause adverse effects in living organisms. Therefore, it is necessary to evaluate the range of concentrations in which these elements would produce beneficial or necessary effects and the concentrations that would be toxic [5].

The current concern regarding the concentrations of heavy metals and metalloids in the environment is reflected in the development of protective legislation and also in the development of remediation techniques for soil, sediments, and water (both surface water and groundwater) that are based on physicochemical and biological processes. Such remediation techniques must be economically viable and environment-friendly so that no further environmental problems are caused.

In this regard, the present report summarizes the existing knowledge on heavy metals and metalloids in the environmental context to facilitate the understanding of the behavior of these elements in various natural ecosystems. First, the main sources, natural as well as anthropogenic, of the compounds of each of these elements are discussed, with a particular focus on the transport agents in the biosphere. Finally, the physicochemical processes involving heavy metal(loid)s and occurring in the aquatic and soil ecosystems are described to better understand the remediation techniques that have been developed in the past few decades and thus better manage the soil pollution problems.

\section{Heavy Metals, Trace Metals, Metals, or Elements?}

In the literature, certain elements of environmental concern are grouped together and assigned various designations, such as metals, heavy metals, trace metals, toxic metals, etc. These groups of elements of environmental concern mostly include metals such as $\mathrm{Zn}, \mathrm{Ni}, \mathrm{Cd}, \mathrm{Cu}, \mathrm{Sn}, \mathrm{Pb}, \mathrm{Fe}$, and $\mathrm{Hg}$, although a few metalloids, such as As, and even non-metals, such as Se, are also included (Figure 1). 


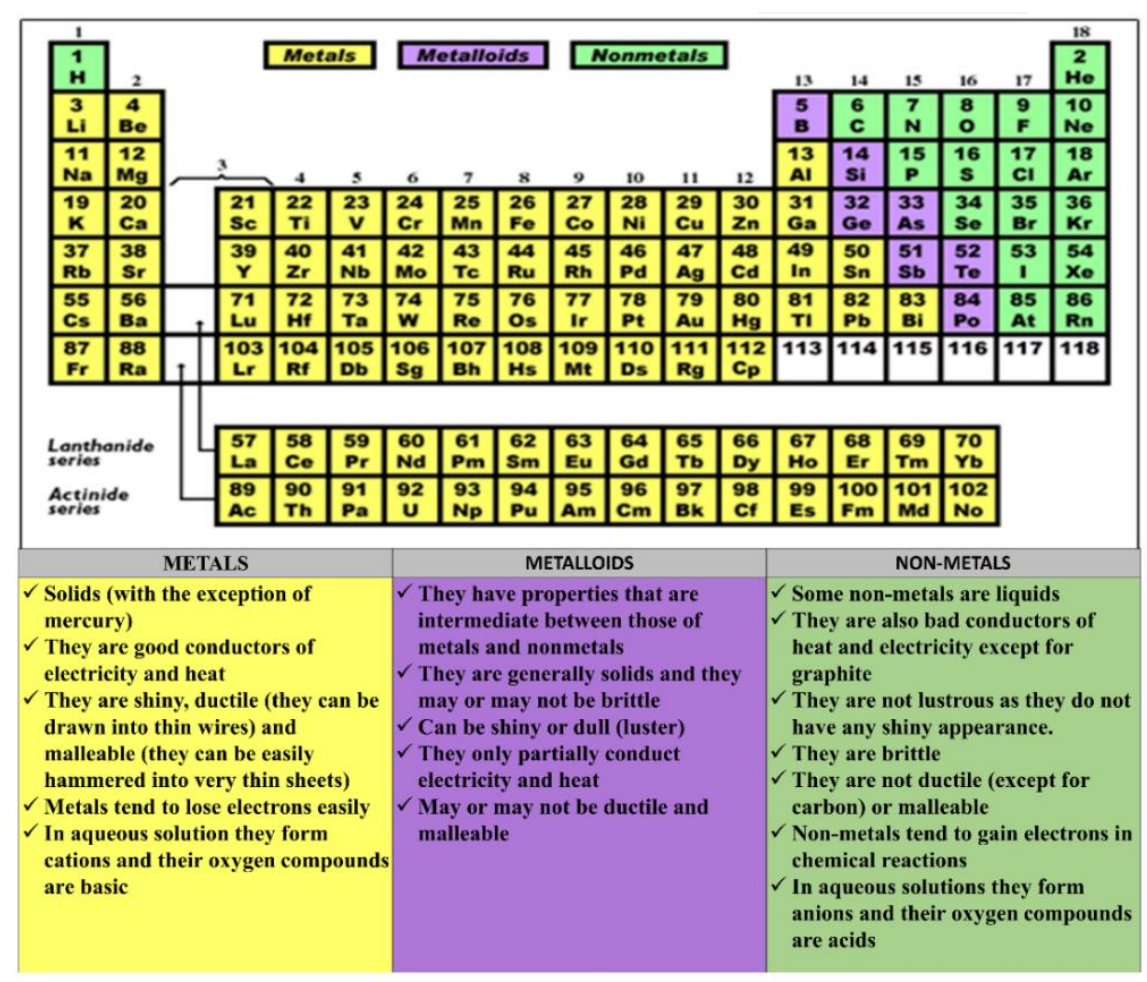

Figure 1 The metals, metalloids, and non-metals in the periodic table.

The use of various terms, including metals, heavy metals, elements, etc., for a group of chemical elements of biological and environmental concern creates confusion as each of these terms is based on a strict definition, due to which a few elements are left out of the group. For instance, when using the term 'heavy metals', As and Se should not be included as these are not metals; however, most environmental studies include these two elements in the 'heavy metals' group.

The term "heavy metal" refers to the metallic elements having a density above a certain threshold value. However, no consensus has been reached on a particular density value to be used as the threshold for this distinction in the literature so far, and different studies have considered different values as the threshold in their analyses, such as $4,4.5,5$, and $7 \mathrm{~g} \mathrm{~cm}^{-3}[6,7]$. Nonetheless, even the elements that have a density below the above-stated density values, which are designated as light metals (e.g., Li, Be, and B), are also of environmental concern.

Another approach to classifying a metallic element as a heavy metal involves the atomic number and atomic weight of the element, such as the elements with atomic number greater than 20 (metals beyond calcium in the periodic table) or the elements with atomic weight greater than that of sodium (23) [8].

Authors such as Duffus (2002) [9] and Hodson (2004) [10] have defended that the term 'heavy metals' should be eliminated from the literature as this term is being used as a synonym for "bad" metals. Hodson, (2004) [10] stated that "whenever one encounters research manuscripts titled "Distribution of heavy metals in...", "Effects of heavy metals on...", or "Uptake of heavy metals by...", one understands that this manuscript would be on pollution and its environmental impact or anthropogenic influences. The authors recommend that the lack of a clear criterion for using these terms should be overcome by the correct grouping and defining of these elements based on their properties according to the periodic table. 
On the contrary, authors such as Batley (2012) [11] are in favor of accepting and continuing the use of the term 'heavy metals' for a group of common elements and compounds of environmental concern, such as the ones composed of the following metals: $\mathrm{V}, \mathrm{Zn}, \mathrm{Cr}, \mathrm{Ag}, \mathrm{Fe}, \mathrm{Co}, \mathrm{Ni}, \mathrm{Cu}, \mathrm{Mo}, \mathrm{Mn}$, $\mathrm{Cd}, \mathrm{Au}, \mathrm{Hg}, \mathrm{Sn}$, and $\mathrm{Pb}$. In a manner, the author recommends the use of this term from an environmental-chemistry and ecotoxicological perspective. While Batley (2012) [11] admits that this definition is not accurate, the author defends that the term serves a practical and profitable purpose. According to Batley, a further precise definition would include transition metals, certain metalloids, lanthanides, and actinides, in addition to just metals. Babula et al. (2008) [12] also share the same opinion and agreed that the term "heavy metals" should include all the above-stated groups of elements.

Furthermore, this group of elements is also, at certain times, designated as "trace elements" or "trace metals", which creates further confusion as not all of such elements of environmental concern meet the criterion of being present in "trace" amounts. An element is considered as a trace element when its presence in the environment is in trace concentrations, i.e., in the range of ppb to less than $10 \mathrm{ppm}$, in different environmental matrices and a few specified sources, such as soil, plant, living organism, groundwater, etc. [13]. However, metals such as Fe and Zn might be present in the soils and/or sediments at concentrations greater than $10 \mathrm{ppm}$ (in the gram range), thereby defying the criterion of trace concentration. Therefore, not all elements/metals of environmental concern could be universally referred to as trace metals or trace elements.

In the field of toxicology and human health, the terms "trace metals" and "trace elements" acquire a further confusing connotation of being related to a low nutritional requirement in a specified organism [9]. The examples of trace metals necessary for good health in humans are listed in Table 1.

Table 1 The metals and metalloids required in nutrition for good health in humans [14].

\begin{tabular}{llll}
\hline & Toxic metals & Probably essential & Proven essential \\
\hline Trace $\left(\mathrm{mg} \mathrm{kg}^{-1}\right)$ & & & $\mathrm{Fe}, \mathrm{Zn}, \mathrm{Cu}$ \\
Ultratrace $\left(\mu \mathrm{g} \mathrm{kg}^{-1}\right)$ & $\mathrm{As}, \mathrm{Cd}, \mathrm{Au}, \mathrm{Pb}, \mathrm{Hg}, \mathrm{Si}$ & $\mathrm{Ni}, \mathrm{V}, \mathrm{Sb}$ & $\mathrm{Mn}, \mathrm{Co}, \mathrm{Se}, \mathrm{Mo}, \mathrm{Cr}$ \\
\hline
\end{tabular}

It is true, as Batley (2012) stated [11], that the terms "heavy metals" and "metals" are widely accepted in the scientific community working on environmental research for defining a range of elements with different characteristics. However, in other fields of chemistry, such as analytical chemistry, biochemistry, organic chemistry, inorganic chemistry, etc., it is important to adjust the terms strictly in accordance with the characteristics of an element according to the periodic table, selecting distinct and precise terms that best fit the requirements.

Since most of the environmental studies consider metals with densities above $7 \mathrm{~g} \cdot \mathrm{cm}^{-3}$, the term "heavy" would be acceptable for these studies. However, in the studies involving As and Se, these elements should be referred to using their chemical names, separately and distinctly from the "heavy metals", as these elements are metalloid and non-metal, respectively. Therefore, it appears suitable to use the term heavy metal(loid)s, which would include heavy metals and the other most common compounds/elements of environmental concern, such as As and Se. In the oral speech, the group corresponding to the above term could be referred to as the "heavy metals and metalloids". 


\section{Sources of Heavy Metal(loid)s Present in the Environment}

The heavy metal(loid)s present in the environment might have origins in natural and/or anthropogenic sources (Figure 2). In addition, certain natural agents, such as wind, vegetation, etc., could serve as effective pathways for the mobility and transport of these metal(loid)s in the biosphere. Since the characteristics of these sources vary widely, these must be treated separately.

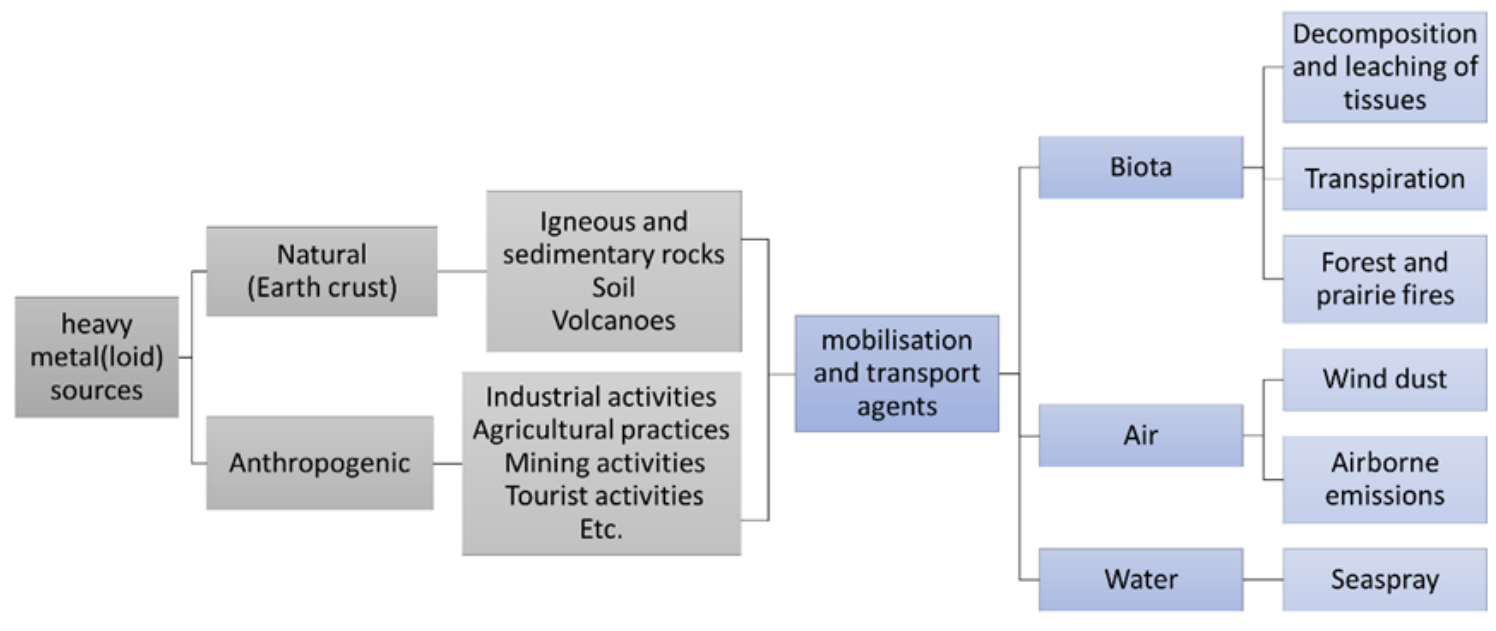

Figure 2 The sources and the mobilization and transport agents in the biosphere that contribute to metal(loid) pollution.

\subsection{Natural Sources}

Natural phenomena, such as weathering of rocks and volcanic eruptions, may release metal(loid)s into the environment to different extents. These natural sources seldom lead to huge impacts as their contributions are minor. Among these sources, rocks, soils, and volcanoes are the most relevant ones.

\subsubsection{Rocks and Soils}

Among the natural sources of metal(loid) release in the environment, rocks and soils are the two main contributors. The magmatic or igneous rocks are formed when the magma cools. These rocks contain various chemical elements in a crystalline network of primary minerals, including heavy metal(loid)s. Certain elements enclosed in the minerals that form these rocks may be released into the environment naturally, such as As is released from arsenopyrite (FeAsS), mercury from cinnabar $(\mathrm{HgS})$, lead from galena $(\mathrm{PbS})$, anglesite $\left(\mathrm{PbSO}_{4}\right)$, and cerussite $\left(\mathrm{PbCO}_{3}\right)$, and chromium which crystallizes as the mineral chromite $\left(\mathrm{FeCr}_{2} \mathrm{O}_{4}\right)$, etc. [15]. Table 2 lists the most common chemical elements present in the magmatic minerals that are components of magmatic rocks.

Table 2 The chemical elements present in the most common minerals that form magmatic rocks [15].

\begin{tabular}{ll}
\hline Mineral & Trace element \\
\hline Olivine & $\mathrm{Ni}, \mathrm{Co}, \mathrm{Mn}, \mathrm{Li}, \mathrm{Zn}, \mathrm{Cu}, \mathrm{Mo}$ \\
Hornblende & $\mathrm{Ni}, \mathrm{Co}, \mathrm{Mn}, \mathrm{Se}, \mathrm{Li}, \mathrm{V}, \mathrm{Zn}, \mathrm{Cu}, \mathrm{Ga}$
\end{tabular}




\begin{tabular}{ll} 
Augite & $\mathrm{Ni}, \mathrm{Co}, \mathrm{Mn}, \mathrm{Se}, \mathrm{Li}, \mathrm{V}, \mathrm{Zn}, \mathrm{Pb}, \mathrm{Cu}, \mathrm{Ga}$ \\
Biotite & $\mathrm{Rb}, \mathrm{Ba}, \mathrm{Ni}, \mathrm{Co}, \mathrm{Mn}, \mathrm{Se}, \mathrm{Li}, \mathrm{V}, \mathrm{Zn}, \mathrm{Cu}, \mathrm{Ga}$ \\
Apatite & $\mathrm{Rare}$ earth elements, $\mathrm{Pb}, \mathrm{Sr}$ \\
Anorthite & $\mathrm{Sr}, \mathrm{Cu}, \mathrm{Ga}, \mathrm{Mn}$ \\
Andesite & $\mathrm{Sr}, \mathrm{Cu}, \mathrm{Ga}, \mathrm{Mn}$ \\
Oligoclase & $\mathrm{Cu}, \mathrm{Ga}$ \\
Albite & $\mathrm{Cu}, \mathrm{Ga}$ \\
Garnet & $\mathrm{Mn}, \mathrm{Cr}, \mathrm{Ga}$ \\
Orthoclase & $\mathrm{Rb}, \mathrm{Ba}, \mathrm{Sr}, \mathrm{Cu}, \mathrm{Ga}$ \\
Muscovite & $\mathrm{F}, \mathrm{Rb}, \mathrm{Ba}, \mathrm{Sr}, \mathrm{Cu}, \mathrm{Ga}, \mathrm{V}$ \\
Titanite & $\mathrm{Rare} \mathrm{earth} \mathrm{elements,} \mathrm{V,} \mathrm{Sn}$ \\
Ilmenite & $\mathrm{Co}, \mathrm{Ni}, \mathrm{Cr}, \mathrm{V}$ \\
Magnetite & $\mathrm{Zn}, \mathrm{Co}, \mathrm{Ni}, \mathrm{Cr}, \mathrm{V}$ \\
Turmaline & $\mathrm{Li}, \mathrm{F}, \mathrm{Ga}$ \\
Zircon & $\mathrm{Hf}, \mathrm{U}$ \\
\hline
\end{tabular}

Another natural source of heavy metal(loid)s is sedimentary rocks. These rocks are formed as a consequence of physical and chemical weathering that leads to the disintegration of rocks into particles (sediment) and ions. Sedimentary rocks are then formed gradually over extended geological periods through the processes of accumulation of these sediments followed by chemical alterations. The third type is metamorphic rocks. Metamorphic rocks are formed in a process characterized by the reorganization and recrystallization of the rock-forming minerals [15].

When the above-stated rocks undergo a gradual disintegration over long periods, it results in the formation of soil. The disintegration process may be physical (such as the weathering process due to the influence of temperature, water, ice, etc.), chemical (soluble minerals are dissolved due to interactions between carbonic acid and water), or even biological (due to the action of microorganisms and plants) [16]. In the disintegration process, the chemical elements that once constituted the original rocks are released into the soil. Therefore, the composition and concentration of heavy metal(loid)s in the soil depend on the parent rock type and the environmental conditions [17] and, as a consequence, are highly varied. The chemical composition of heavy metal(loid)s in the soil reflects the chemistry of the parent rock from which these were released. For instance, the soils containing high levels of $\mathrm{Mn}, \mathrm{Co}, \mathrm{Ni}$, and $\mathrm{Cu}$ could have originated from igneous rocks, such as olivine, augite, and hornblende, while the soils originating from sedimentary rocks, such as shale (mainly), limestone, and sandstone, exhibit the highest concentrations of $\mathrm{Cr}, \mathrm{Mn}, \mathrm{Co}, \mathrm{Ni}, \mathrm{Cu}, \mathrm{In}, \mathrm{Cd}, \mathrm{Sn}, \mathrm{Hg}$, and $\mathrm{Pb}$ [18]. If, on the other hand, the soil has been formed from basalt (Table 3 ), a rock type with high levels of $\mathrm{Cr}$, Co, and $\mathrm{Ni}$, it would contain higher concentrations of these elements compared to the soil formed from the granite rock.

Table 3 The average values of metal(loid)s and non-metals (in ppm) contents in certain rocks types [15].

\begin{tabular}{lllllll}
\hline $\begin{array}{l}\text { Metal(loid) } \\
\text { (ppm) }\end{array}$ & ${\text { Granite }{ }^{[a]}}^{\text {(ppmalt }{ }^{[a, b]}}$ & Shale $^{[c]}$ & $\begin{array}{l}\text { Ocean } \\
\text { Clay }{ }^{[c]}\end{array}$ & Limestone & $\begin{array}{l}\text { Deep-Sea } \\
\text { Carbonate }\end{array}$ \\
\hline Al (\%) & 7.2 & 8.2 & 8.0 & 8.4 & 0.42 & 2.0
\end{tabular}




\begin{tabular}{lllllll} 
As & 2 & 2.2 & 13 & 13 & 1 & 1 \\
Be & 3 & 0.7 & 3 & 2.6 & $0 . X$ & $0 . X$ \\
Cd & 0.13 & 0.21 & 0.3 & 0.03 & 0.3 & 0.0 X \\
Co & 4 & 47 & 20 & 74 & 0.1 & 7 \\
Cr & 10 & 185 & 100 & 90 & 11 & 11 \\
Cu & 20 & 94 & 50 & 250 & 4 & 30 \\
Fe (\%) & 1.42 & 8.6 & 5.1 & 6.50 & 0.38 & 0.9 \\
Hg (ppb) & 0.03 & 0.09 & 0.4 & 0.03 & 0.04 & $0.0 X$ \\
Mn (\%) & 0.045 & 0.18 & 0.09 & 0.07 & 0.11 & 0.1 \\
Mo & 1 & 1.5 & 2.627 & 0.4 & 3 & \\
Ni & 10 & 145 & 60 & 230 & 20 & 30 \\
Pb & 17 & 7 & 20 & 30 & 9 & 9 \\
Sb & 0.22 & 0.6 & 1.5 & 1 & 0.2 & 0.15 \\
Sc & 7 & 27 & 16 & 19 & 1 & 2 \\
Se & 0.05 & 0.05 & 0.6 & 0.17 & 0.08 & 0.17 \\
Sn & 3 & 1.5 & 6 & 1.5 & $0 . X$ & $0 . X$ \\
Ti (\%) & 0.12 & 1.14 & 0.60 & 0.46 & 0.04 & 0.08 \\
TI & 2.3 & 0.21 & 1.4 & 0.8 & $0.0 X$ & 0.16 \\
V & 50 & 225 & 140 & 120 & 20 & 20 \\
Zn & 50 & 118 & 85 & 200 & 20 & 35 \\
(a) [19]; (b) [20]; (c) [21] & & & & & \\
\hline
\end{tabular}

\subsubsection{Volcanoes}

Volcanoes are another natural source from where toxic elements are released into the environment. While the volcanic material expelled during a volcanic eruption also releases nutrients, such as nitrogen, phosphorus, potassium, calcium, sodium, magnesium, etc., into the environment, the levels of toxic elements released, such as heavy metals and metalloids ( $\mathrm{Al}, \mathrm{In}, \mathrm{Mn}, \mathrm{Pb}, \mathrm{Ni}, \mathrm{Cu}, \mathrm{As}$ and $\mathrm{Hg}$, etc.), are higher [22].

Volcanic ash flies in the air and is spread around along with the wind, thereby reaching larger distances and affecting sites situated far away from the site of the volcanic eruption. Ochota et al. (2012) [23] conducted a study to determine the contents of Pb, Cd, $\mathrm{Zn}, \mathrm{Fe}, \mathrm{Mn}, \mathrm{Cu}$, and $\mathrm{Cr}$ in the samples of moss bags exposed to atmospheric dust containing volcanic ash in Sosnowiec (Poland) after the eruption event of the Eyjafjallajökull volcano (the last eruption occurred on March 20, 2010) in Iceland. The results revealed a great increase in the content of heavy metal(loid)s in most of the samples exposed to environmental dust after the volcanic eruption in Iceland.

\subsection{Anthropogenic Sources}

The heavy metal(loid)s present naturally in the environment do not cause much environmental pollution. The pollution in soil, water, and/or the atmosphere is rather due to anthropogenic activities, which disrupt the geochemical cycle of the elements, thereby leading to the accumulation of toxic elements in any of the matrices. For instance, mining activities bring to the surface the minerals, which also contain heavy metal(loid)s, that are located at great depths within the earth in nature. The other reported anthropogenic sources of the heavy metals and metalloids existing in 
the environment include industrial, agricultural, domestic, traffic, pharmaceutical, and atmospheric sources.

The release of these elements from anthropogenic sources into the environment might be punctual (factories effluents, sewage waste, etc.) or diffuse (runoffs from land, roads, and roofs, etc.).

\subsubsection{Industrial Sources}

Most of the existing industries utilize heavy metal(loid)s in their production processes, thereby yielding harmful waste. Despite improvements in the process technologies, which have improved and maximized the efficiency of the industrial processes, a state of zero waste production has not been reached so far. The conventional water and solid waste management techniques are inadequate to eliminate the entire pollution load, and a certain amount of waste material is released into the environment. Moreover, there are a few industrial sources that dump their waste straight into the environmental matrices. Environment pollution has, as a consequence, reached a level that is threatening to human health, plants, animals, as well as aquatic biota [24].

The anthropogenic sources of heavy metal(loid)s in the environment mainly include industrial emissions, such as those from transportation, coal combustion, and fugitive particulate emissions. Among the other sources is the urban and industrial waste treatment, incineration in particular. For instance, $\mathrm{Cd}$ and $\mathrm{Ni}$ are released into the environment due to the burning of residual municipal and sewage wastes, incineration, combustion of coal and fuel oil, urban refuse, mine tailings, and smelter slag and waste [25].

The mining activities generate huge amounts of metal(loid)s that are subsequently discharged into the environment. For instance, $\mathrm{Cd}$ is present in $\mathrm{Zn}$ ores as a guest-element and has a geochemical similarity and origin to $\mathrm{Zn}$, due to which the extraction processes conducted for $\mathrm{Zn}$ inevitably release Cd into the environment [19]. In 1998, a spill of mine tailing occurred in Aznalcollar (Spain), causing negative effects that threatened the environment. In that accident, huge amounts of acidic water $(\mathrm{pH} \approx 3$ ) and sludge containing high levels of heavy metal(loid)s, including $\mathrm{Zn}, \mathrm{Cd}, \mathrm{Ag}$, $\mathrm{Pb}, \mathrm{Cu}, \mathrm{Sb}, \mathrm{As}, \mathrm{Co}, \mathrm{Ti}, \mathrm{Bi}, \mathrm{Hg}$, and $\mathrm{Se}$, were dumped into the surroundings of a natural park (Doñana Park). The short-term impacts caused by this dumping event included drastic changes in the properties of water (strong decrease in the water $\mathrm{pH}$ and reduced dissolved oxygen levels of $0.5-1$ $\mathrm{g} / \mathrm{L}$ ) and death of the local fauna due to blows and gill blocking. The long-term impacts included sublethal effects on the immune system, DNA damage, adrenocortical stress response, and bone development and metabolism in various organisms [20].

The use of $\mathrm{Cd}$ is common in various industrial processes, such as the production of alloys, pigments for plastic materials, coatings for steel and non-ferrous metals, etc. Moreover, $\mathrm{Cd}$ is essential for the production of electronic instruments and batteries. The current trend of increasing environmental awareness and responsibility in developed countries has triggered a reduced usage of $\mathrm{Cd}$ as well as an increase in the recycling of products. In effect, approximately $22 \%$ of the production of $\mathrm{Cd}$ comes from the recycling of $\mathrm{Ni}-\mathrm{Cd}$ batteries [21].

The industrial sources of $\mathrm{Cu}$ include regular transportation, manufacturing, currency, construction (roofing, decoration, etc.), and electricity transportation such as conductive dyes. $\mathrm{Cu}$ is used in the production of brass alloys for vehicles and is present in cylinder head gaskets, oil leak sumps, and brake linings. Al-Khashman (2004) [26] reported high concentrations of Cu in street dust 
in the Karak Industrial Estate (Jordan) and linked these elevated Cu concentrations with motor vehicles as the study region was close to a car service site.

$\mathrm{Pb}$ is released to the environment from fossil fuels burning, mining, manufacturing, heavy metal products (solder and pipes), and devices to shield X-rays. Certain kinds of batteries also use $\mathrm{Pb}$ in their composition and are referred to as lead-acid batteries. Since the late 1970s, there has been an effort to reduce the use of $\mathrm{Pb}$ in various products, such as gasoline, paints for residential applications, cans for food products, and plumbing systems [3]. López et al. (2019) [27] detected high levels of Pb in the soil of an urban farm, which was attributed to the construction demolition wastes dumped into the soil at the site close to where the urban farm was located. These construction wastes contained white paints, which are characteristic of the Mediterranean countries. The white pigment in these paints contains $\mathrm{Pb}$ (hydrocerussite, $2 \mathrm{PbCO}_{3} . \mathrm{Pb}(\mathrm{OH})_{2}$ ) in a concentration range of $6.0 \%-$ $18.6 \%$, which was the reason for the high lead concentration in the soil [28].

As is used as an alloying agent extensively in various industries, such as glass, pigment, textile, paper, adhesive, wood preservative, and ammunition production industries. In addition, As is used in the tanning of hides, pesticides, feed additives, and pharmaceuticals. In medicine and veterinary sciences, As is used in the treatment of various diseases, such as syphilis, amoebic dysentery, and trypanosomiasis, and even for the eradication of tapeworms in sheep and cattle [29].

Industrial chromium is released into the environment due to various activities, such as heavy metal processing, chromium production, stainless steel welding, ferrochrome production, and pigment production, etc. [3]. In addition, it is widely used in leather tanning [30], in which the chromium salts used are not chemically fixed during the processing of leather and are released as liquid effluents. So far, it has been nearly impossible to replace $\mathrm{Cr}$ in the leather tanning process. Therefore, a technology capable of cleaner production is being developed to reduce the load of chromium salts into the effluents [30]. Tariq et al. (2006) [31] studied the environment around the tanneries and reported contamination of the soil and water in the study region due to the release of effluents containing high levels of $\mathrm{Cr}$, $\mathrm{Fe}$, and $\mathrm{Pb}$ from the tanneries without any pretreatment.

$\mathrm{Ni}$ and $\mathrm{Zn}$ have several industrial and commercial applications due to their high resistance to corrosion and temperature. $\mathrm{Ni}$ and its compounds are used in the production of stainless steel and other Ni alloys, as well as in chemical and food processing industries, particularly as catalysts and pigments [25]. $\mathrm{Zn}$ is used widely in the production of galvanized metals and metallic surfaces that are used as building materials (railings, chain-link fences, plumbing and stormwater drainage pipes, etc.) and the manufacturing of office furniture. $\mathrm{Ni}$ and $\mathrm{Zn}$ are also used in the motor vehicle industry, specifically in rubber tires, motor oil, hydraulic fluids, and brake pads (although a few authors have stated the brake pads as a source of copper rather than zinc [32]).

$\mathrm{Hg}$ has been used extensively in the electrical industry (switches, thermostats, and batteries) and other industrial processes, such as caustic soda production, nuclear reactors, antifungal agents for wood processing, precious metals, and pharmaceuticals [3]. Hg was used as an ingredient in latex paints and other types of paint for a long time, which exerted negative effects on human health. Phenylmercuric acetate was used as a preservative to prolong the shelf life of the interior latex paint. According to a study, the topsoil in Beijing, which is one of the most populated cities in the world, has significant contamination of $\mathrm{Hg}$ and other polluting metals related to the use of paints in old constructions [33]. It is reported that the weathering of $\mathrm{HgS}$ used as a red pigment in ancient buildings and coal-burning are two significant contributors to the high concentrations of $\mathrm{Hg}$ in soils [34]. Exposure to $\mathrm{Hg}$, either in soil or paints, is harmful to human health. Mercury poisoning 
(acrodynia) has been detected in a child that was exposed to paint fumes with a mercury content of $4.7 \mathrm{mmol} / \mathrm{L}$ [35]. The Environmental Protection Agency recommends a $\mathrm{Hg}$ content of $1.5 \mathrm{mmol} / \mathrm{L}$ or less in paints.

\subsubsection{Agricultural Sources}

Animal farming and intense agricultural practices use potentially toxic elements, such as inorganic fertilizers, liquid and solid manure (or their derivates, composts, or sludge), pesticides, insecticides, etc.

For instance, $\mathrm{Zn}$ and its compounds (zinc oxide, zinc sulfate, and zinc oxysulfates) are used widely in agriculture as fertilizers, fungicides, or even pesticides [32]. The long-term use of these compounds in an intensive agriculture system might lead to the accumulation of the $\mathrm{Zn}$ element in the soil profile, from where the heavy metal(loid) pollution ultimately reaches the surface and/or groundwater and even the atmosphere [36].

Fertilizers and pesticides are responsible for $\mathrm{Cd}$ accumulation in the soil-plant environment. Since $\mathrm{Cd}$ is commonly present as an impurity in phosphatic rocks, when a phosphatic fertilizer is applied, $\mathrm{Cd}$ is released into the soil [37]. This $\mathrm{Cd}$ is then absorbed by crops, trees, and animals, where it accumulates and could later reach the humans via the food chain, threatening human health. One of the most common examples of this is the "Itai-Itai disease", which occurred in Japan during the 1950s. This disease manifested in the people who consumed rice and soybean contaminated with $\mathrm{Cd}$. The high $\mathrm{Cd}$ contamination levels in the rice crops were a consequence of the uncontrolled discharge of $\mathrm{Cd}$ from mineral refinery factories into the Jenzu River basin [38].

Intensive agriculture is aimed at fighting plagues or undesirable vegetal species and maximizing crop production. This objective is achieved with the wide application of insecticide, herbicide, and fungicide solutions or even sheep dips, which contain several toxic elements in abundance. For instance, As is present in various inorganic compounds, such as calcium arsenate, lead arsenate, and sodium arsenate [37], and the application of such compounds to soil serves as, in addition to a source of nutrients, an important source of As to the soil.

The antifungal and antimicrobial properties of $\mathrm{Cu}$ have also expanded its application range [39]. However, the misuse of such $\mathrm{Cu}$-containing products might lead to high concentrations of $\mathrm{Cu}$ in the soil, which could affect the soil biota and even alter the $\mathrm{C}$ and $\mathrm{N}$ cycles in the soil, thereby leading to reduced soil fertility [40].

Since the aim of using Cu-containing fungicides is to extend the protection provided by these fungicides to fungal diseases as well, these fungicides contain $\mathrm{Cu}$ in its inorganic form. This inorganic Cu form is insoluble in water and is, therefore, not washed off easily by irrigation water or rainwater, thereby providing longer protection against diseases [41]. López et al. (2019) [27] detected high concentrations of $\mathrm{Cu}$ in the leaves of urban plants and linked it to the use of copper-based fungicides, even though traffic pollution is usually considered the main source of $\mathrm{Cu}$ released into the environment in urban regions.

Lastly, another source of metal(loid)s released into soils is manure. Manure products contain elements, such as $\mathrm{As}, \mathrm{Co}, \mathrm{Cu} \mathrm{Fe}, \mathrm{Mn}, \mathrm{Se}$, and $\mathrm{Zn}$, which serve as nutrients for the livestock and/or poultry, preventing the development of diseases, improving weight gains, and feed conversion efficiency, and increasing the egg production. The excess nutrients that are not assimilated by the organisms are excreted through the urine or feces, which is the reason for the high content of toxic 
compounds in the manure [42]. For instance, in England and Wales, approximately $25 \%-40 \%$ of the total annual $\mathrm{Cu}, \mathrm{Ni}$, and $\mathrm{Zn}$ inputs to the agricultural lands were derived from animal manure [43].

Besides manure, the water used for irrigating the fields also serves as a source of certain elements that are released into the soil as the wastewater treatment process is not $100 \%$ efficient. For instance, the $\mathrm{Pb}$ content in the soil could be a consequence of the release of industrial wastewater into the soil, particularly in the soils of densely populated areas [44].

\section{Mobility and Transport Agents in the Biosphere}

Environmental agents, such as the biota, air, and water, are involved in the mobility and transport cycles of metal(loid)s in the biosphere. For instance, plants absorb and accumulate heavy metal(loid)s and other toxic elements in their roots, shoot tissues, leaves, and stems. The subsequent decomposition and leaching of plant tissues then affect the soils, sediments, and water. Therefore, it is possible to utilize plants for removing heavy metal(loid)s and other toxic elements (phytoremediation) in water and soil treatments. In addition, atmospheric emissions of these toxic elements occur due to the transpiration process of plants. The toxic elements are first transformed into volatile forms within the plant and then released into the atmosphere via transpiration. This process, known as phytovolatilization, has been used for the remediation of soils polluted with $\mathrm{Hg}$ and Se [45].

The atmospheric emissions of volatile elements also occur during forest and prairie fires (e.g., elements, such as $\mathrm{Hg}$ and $\mathrm{Se}$, are present in the carbonaceous matter released during forest fires) [46]. Finley et al. (2009) [47] estimated that the atmospheric emissions of $\mathrm{Pb}$ and $\mathrm{Hg}$ together with other metals during a forest fire were similar to those of anthropogenic origins, such as industrial processes and urban pollution. Moreover, Finley et al. (2009) [47] reported that the global $\mathrm{Hg}$ emissions from wildfires included an estimated $890,000 \pm 490 \mathrm{~kg} /$ year for gaseous elemental $\mathrm{Hg}$ and $170 \pm 100 \mathrm{~kg} /$ year for particle-bound $\mathrm{Hg}$.

Deserts and coastal regions may also serve as the sources of metal(loid)s due to the action of various environmental agents, such as wind. In deserts, the wind currents may cause the dust containing toxic elements to reach the sites located at great distances from the original site.

For instance, the Sahara dust has high levels of $\mathrm{Fe}$ and $\mathrm{Mn}, \mathrm{In}, \mathrm{Cr}, \mathrm{Ni}$, and $\mathrm{Pb}$ present in lesser amounts [46]. The nearby countries such as Spain and other Mediterranean nations, therefore, receive the "red rain", which is a meteorological event involving the transport of the aforementioned dust from the North African sources. López et al. (2019) [27] reported that this dust deposition affected the crops in an urban farm located in the largest city of Sevilla (Spain). The sample crops of lettuce and broad bean exhibited high concentrations of crustal metals, including $\mathrm{Fe}, \mathrm{Co}, \mathrm{Mn}$, and $\mathrm{Cr}$, which was attributed to the Saharan dust deposition. Naderizadeh et al. (2016) [48] conducted studies in the province of Bushehr (southwestern Iran), where dust storms had become a major environmental concern, and demonstrated that atmospheric dust particles served as significant pollutants in the environment as these contained high levels of toxic metals, such as $\mathrm{Fe}, \mathrm{Ni}, \mathrm{Cr}, \mathrm{Co}$, and $\mathrm{Mn}$, which originated from natural sources.

In coastal areas, emissions of these pollutants occur due to ocean activity, which generates particles, aerosols, and sea sprays (approximately $5 \mathrm{mg} \cdot \mathrm{m}^{-2} \cdot \mathrm{d}^{-1}$ sea salt particles are released) [49]. The element and the transport agent (wind, rain, etc.) together determine the physical form in which these emissions would be transported. For instance, $\mathrm{Cu}, \mathrm{Pb}$, and $\mathrm{Zn}$ are transported as 
particles, while volatile metals such as $\mathrm{Hg}$ and other elements such as $\mathrm{Se}, \mathrm{Sb}$, and As may be transported either in gaseous form or enriched in particles [15]. Irrespective of the form which is transported, the two-way sea-land transport via the atmosphere provides a mixed marinecontinental composition to these elements. The metal-enriched particles generated in the sea-spray increase the concentration of certain metals in the environment close to the marine environment, such as air, rain, seaside area, etc. This has been confirmed previously in 1974 by Peirson et al. [50], who reported a higher content of metals in the rainwater in the atmosphere above the North Sea. Another study conducted by Van Malderen et al. (1996) [51] over the southern bight of the North Sea revealed a higher content of $\mathrm{Cr}$ in the aerosols particles collected in the air mass of marine origin, which was attributed to the recycling of previously deposited material that was reinjected into the atmosphere due to sea-spray.

A remarkable atmospheric deposition of heavy metal(loid)s occurs in plants and soil, independent of the time scale. In effect, atmospheric deposition is responsible for over $90 \%$ of the total plant uptake of $\mathrm{Pb}$ [52] and over $50 \%$ of the plant uptake of $\mathrm{Cd}$ [53].

In certain industrial activities, such as electricity generation based on coal burning, generate ashes rich in heavy metal(loid)s. The generated ashes are ultimately dumped on land, because of which the soils of the regions surrounding coal-fired electricity generator plants are contaminated with heavy metal(loid)s. Krishna and Govil (2007) [54] conducted a study on the soil in the city of Surat in Gujarat (India) and reported that the ashes generated in this activity increased the Cr levels in the soils of the regions close to the industry.

\section{Reactivity and Transport of Heavy Metal(loid)s in Soils and Aquatic Ecosystems}

The mobility of heavy metal(loid)s through the different "compartments" or components of an ecosystem involves various biological, geological, and chemical processes. Moreover, metal(loid)s may also become incorporated as components of the biota as essential elements necessary for the life cycle of the organisms. However, when these elements are present in high concentrations in the environment, the bioaccumulation of these elements in the tissues of certain organisms, such as filter organisms (e.g., bivalves) or microorganisms, may reach toxic/lethal concentrations or the elements might be adsorbed in the cell walls of the microorganisms, ultimately damaging the cells [30].

\subsection{Heavy Metal(loid)s in Soils}

The metal(loid) concentration in a soil solution is calculated as the sum of the individual concentrations of different free ions in the solution, the concentration of soluble organic and inorganic metal(loid) complexes, and the concentration of heavy metal(loid) components of the mobile colloidal material [55].

In separate studies, Tangahu (1991) [56] and McLean and Bledsoe (1992) [57] established seven possible states in which these elements might be present in soils:

(1) in the soil solution as free metal(loid) ions, in complexes or associated with moving colloids;

(2) in exchange positions with the inorganic constituents of the soil;

(3) adsorbed onto the insoluble organic matter;

(4) specifically adsorbed onto the inorganic constituents (Fe and Mn oxides);

(5) precipitated in the form of carbonates, phosphates, hydroxides, etc.; 
(6) as the components of the structure of secondary minerals;

(7) as the components of the structure of primary minerals.

Heavy metal(loid)s of anthropogenic origin are usually present in the first five forms, while the ones originating from natural sources occur in any of the above-stated forms, depending on the process of soil formation and evolution. However, when the heavy metal(loid)s are present in the environment in states (1) and (2), their availability to the living organisms is high.

Upon entering the soil system, the heavy metal(loid)s may undertake several different pathways (Figure 3). The heavy metal(loid)s may be stored or transported through internal mechanisms, which mainly include the formation of complexes with organic and inorganic ligands, oxide-reduction reactions, precipitation-dissolution reactions, immobilization by soil organisms, and adsorptiondesorption reactions [52].

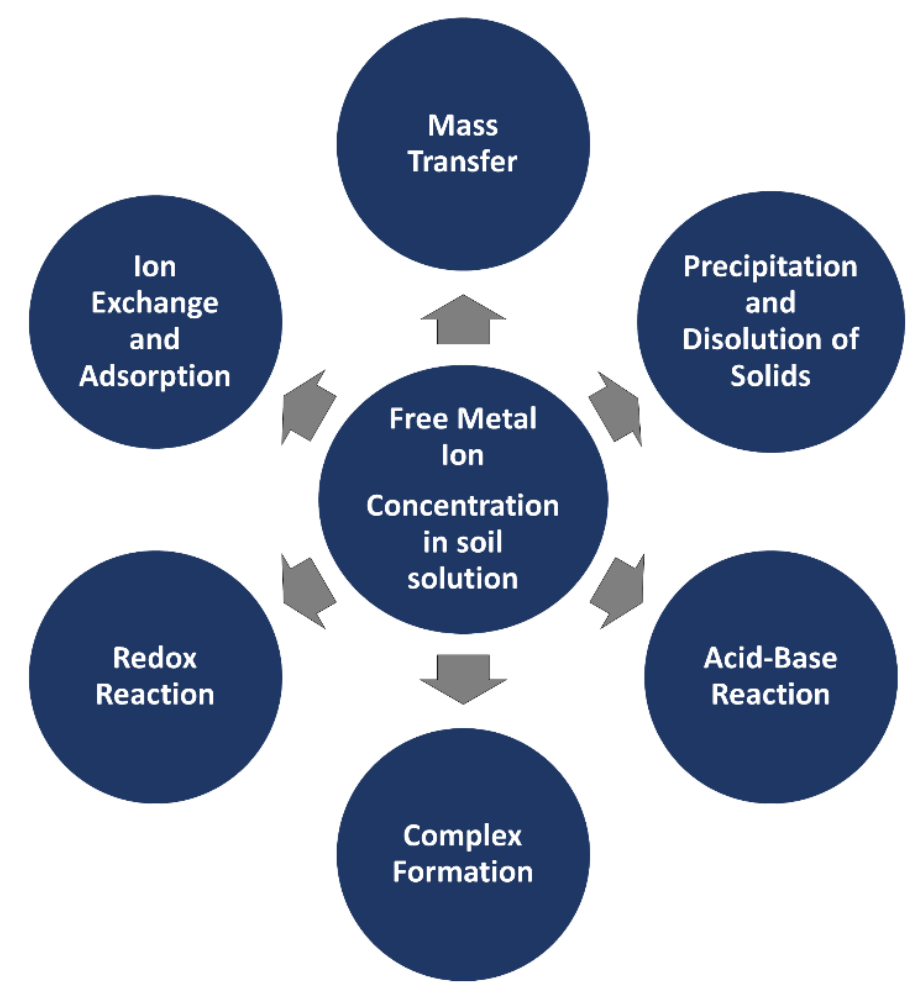

Figure 3 Principal processes governing the concentrations of different metal(loid)s in the soil solution [55].

Heavy metal(loid)s undergo a series of chemical reactions involving solid and aqueous phases of the soil, which vary both spatially and temporally. Therefore, the chemical composition of the soil solution is dynamic and, therefore, influenced by the balance between these two phases. The solid phase is formed by phyllosilicates, which include clay minerals, oxy-hydrides such as Mn hydrides, Fe and Al oxides, and particulate organic matter. The aqueous phase comprises water and dissolved constituents, such as free metal(loid) ions, complexed metal(loid) ions, dissolved organic carbon, and other ligands [52], which provide a mobile medium for both chemical reactions and metal(loid) transfer and circulation from the soil to the organisms or even to the aquatic environment. 


\subsubsection{Complex Formation}

A complex is a molecule formed by a central atom or ion, which in this case would be a metal(loid) (e.g., $\mathrm{Cd}^{+2}, \mathrm{Zn}^{+2}, \mathrm{Cr}^{+3}$, etc.), bonded to other atoms or molecules surrounding the central atom in a specific geometric pattern (e.g., $\mathrm{ZnSO}_{4}{ }^{0}, \mathrm{CdHCO}_{3}{ }^{+}, \mathrm{Cr}(\mathrm{OH})_{4}{ }^{-}$). These surrounding atoms or molecules, referred to as ligands, may be of inorganic $\left(\mathrm{SO}_{4}^{-2}, \mathrm{HCO}_{3}{ }^{-}, \mathrm{Cl}^{-}, \mathrm{OH}^{-}, \mathrm{PO}_{4}{ }^{-3}, \mathrm{NO}_{3}{ }^{-}\right.$, and $\left.\mathrm{CO}_{3}{ }^{-2}\right)$ or organic nature (compounds of low molecular weight, such as aromatic, aliphatic, and amino acids), or soluble constituents of fulvic acid (FA) and humic acid (HA).

Humic acid is the most abundant natural ligand with a high affinity that enables it to chelate several metals ions present in the environment. The HA-metal(loid) complex is capable of modifying the properties of the metal(loid) ions. For instance, metal(loid) solubility may be increased when heavy metal(loid)s are present in a complex with free HA, while the solubility is decreased when heavy metal(loid)s are scavenged by humic films present on the mineral surfaces [58]. As a consequence, in reverse effect, the solubility of the metal(loid) affects its bioavailability and toxicity in the environment. In addition, these heavy metal(loid) complex species may determine the mobility of the metal(loid)s through the soil matrix via the modification of the transportation of the free ions.

It is noteworthy that the formation of complexes with the metal(loid) ions produces charged species (positive, negative, or neutral), because of which the adsorption of the complexed ions is different from that of the free ions. For instance, the complexation of $\mathrm{Cd}^{2+}$ with the chloride ligand produces the following differentially charged species: $\mathrm{Cd}^{2+}, \mathrm{CdCl}^{+}, \mathrm{CdCl}_{2}{ }^{0}, \mathrm{CdCl}_{3}{ }^{-}$[55].

Benjamin and Leckie (1982) [59] stated that the chemical compound resulting from the interaction between a metal(loid) ion and a ligand could be a complex species that is capable of adsorbing onto the soil relatively weakly or strongly compared to the free metal(loid). Generally, when the metal(loid) complex has a reduced positive charge, the adsorption of this complex on a negatively charged surface is also lower.

\subsubsection{Oxidation and Reduction}

Oxidation-reduction reactions (redox reactions) of metal(loid)s play a crucial role in governing the transformation, mobility, and toxicity of metal(loid)s in the environment as these allow the elements to occur in both oxidized and reduced forms. The oxidation-reduction reactions may occur through abiotic and biotic processes. The former may occur on the surfaces of humic substances, sulfides, ferrous species, and Fe(III) and Mn oxides. Redox reactions govern the reactivity of Fe and Mn oxides, which are the major sinks of heavy metal(loid)s in the soil. Mn oxides serve as electron pumps for a large number of redox reactions that are unique to common minerals in the soil [60].

Metal(loid)s such as $\mathrm{As}, \mathrm{Cr}, \mathrm{Hg}$, and Se (non-metal) are quite sensitive to the redox conditions in the soil. $\mathrm{Cr}$ is a suitable example of how a metal(loid) changes from being an essential nutrient to plants and even to animals when in the $\mathrm{Cr}$ (III) form to a toxic element when in the $\mathrm{Cr}(\mathrm{VI})$ form. The environmental behavior of these two forms of $\mathrm{Cr}$ is also different. While $\mathrm{Cr}(\mathrm{VI})$ in the soil is mobile and readily available, $\mathrm{Cr}(\mathrm{III})$ may be present in the adsorbed or precipitated condition. Since the toxicity and mobility of elements depend on their oxidation states, all reactions that reduce $\mathrm{Cr}(\mathrm{VI})$ to $\mathrm{Cr}$ (III) are of great importance. The dominant reductants in these processes are organic compounds, sulfides, agents such as $\mathrm{Mn}(\mathrm{IV})$, and ferrous species [61]. Another example of an 
element for which the redox and adsorption reactions govern its mobility and distribution is As. The reduced form of As is $\mathrm{As}(\mathrm{III})$, which exhibits higher toxicity and mobility compared to $\mathrm{As}(\mathrm{V})$ [62]. Other species, such as elemental arsenic $[\mathrm{As}(0)]$ and/or arsine $\left(\mathrm{H}_{2} \mathrm{As}\right)$, may also be present in the soil and sediment.

Another parameter that is affected by the oxidation status of the heavy metal(loid) is its solubility. Heavy metal(loid)s are less soluble when in a higher oxidation state and ionic form [63]. It is reported that $\mathrm{Pb}, \mathrm{Cd}$, and $\mathrm{Zn}$ exhibit increased solubility with diminishing redox potential under the same $\mathrm{pH}$ value [64]. Therefore, for the above-stated three heavy metal(loid)s, the redox potential values provide valuable information regarding their bioavailability in the soil. Oxidized soils have redox potential values ranging from +400 to $+700 \mathrm{mV}$, while reduced soils present values in the range of -250 to $-300 \mathrm{mV}$ [65].

Moreover, biotic redox reactions are involved in biological activity, particularly for $\mathrm{As}, \mathrm{Cr}, \mathrm{Hg}$, and $\mathrm{Se}$. In the case of the Hg element, bacteria have a higher significance compared to the eukaryotic cells in the redox process. The mercury-resistant bacterial species Shewanella oneidensis transforms the reactive $\mathrm{Hg}(\mathrm{II})$ into metallic $\mathrm{Hg}(0)$ through an enzymatic reduction in a process that requires an electron donor [66]. In the case of the $\mathrm{Hg}$ element, this transformation might be subjected to volatilization losses. On the other hand, the As present in the soil and sediment, when oxidized to As(V) by bacteria [67], is strongly retained in the inorganic components of the soil. Therefore, the biotic oxidation of As leads to its immobilization in the soil or sediment, different from $\mathrm{Hg}$.

\subsubsection{Methylation and Demethylation}

Methylation is a biological process that reduces the toxicity of heavy metal(loid)s in the soil and sediment. This process is mediated by microorganisms referred to as the methylators, which transform the heavy metals into their respective less-toxic hydride or methylated forms. The methylated or hydride compounds exhibit lower boiling points and/or higher vapor pressure, allowing rapid volatilization. This process involving methylation followed by volatilization of the metal(loid)s might lead to the elimination of, for example, As, $\mathrm{Hg}$, and Se from the ecosystems [68] containing organic matter serves as a methyl group donor for the process [61]. The biochemical methylation and volatilization of inorganic As is considered to be a detoxification process of this element due to the formation of volatile compounds of As, such as alkylarsines, which are easily lost to the atmosphere [69].

Methylation of $\mathrm{Se}$ is also a major detoxification process of this element and is catalyzed biologically [70]. In the methylation process of Se in soils, fungi exhibit relatively higher activity compared to other microorganisms, although certain Se-methylating bacterial isolates have also been reported [52].

\subsubsection{Adsorption and Desorption}

Adsorption may be defined as the interaction of an element or molecule that is in a liquid phase with the surface of a solid phase. This interaction occurring at the solid-liquid interface leads to the accumulation of ions or molecules. In soil, the adsorption and desorption phenomena are key processes governing both reactivity and bioavailability of heavy metal(loid)s. Therefore, the accumulation and removal of heavy metal(loid)s in the soil could be associated with the adsorption and desorption processes, respectively. 
This process of adsorption of ions onto the soil and its constituents is influenced by several parameters, such as soil components, $\mathrm{pH}$, the speciation metal(loid) ion involved, and metal(loid) competition.

Both inorganic and organic elemental components of the soil are involved in the adsorption process. The most important inorganic components are colloids, such as clays (montmorillonite and kaolinite), iron and manganese oxides and hydroxides, metal carbonates, phosphates, and amorphous aluminosilicates [71]. The organic components include living organisms such as algae or bacteria, soluble biochemicals (carbohydrates, polysaccharides, lignin, proteins, amino acids, organic acids, etc.), and insoluble humic substances (insoluble polymers of aliphatic and aromatic substances produced due to microbial activity) that provide interfaces for metal(loid) adsorption [55].

The $\mathrm{pH}$ value also plays a role in the adsorption process. The adsorption of metals is higher when the soil has a higher $\mathrm{pH}$ value. This is because a high $\mathrm{pH}$ value increases the number of surfaces with a negative load, thereby increasing the affinity of the soil for the heavy metal(loid)s. Omar and AlItawi (2007) [72] reported that $\mathrm{pH}$ determined the adsorption process of the lead ions on kaolinite. This effect might be explained by the influence of $\mathrm{H}^{+}$ions on the formation of complex ions. The formation of complexes during the adsorption process occurs through the interaction of the metal(loid) ions with the negatively-charged sites $\left(\mathrm{SiO}^{-}\right)$and the lattice hydroxyl groups (Si-OH). For instance, the adsorption of $\mathrm{Pb}^{+2}$ onto the soil is due to its interaction with $\mathrm{SiO}^{-}$and $\mathrm{Si}-\mathrm{OH}$ in the soil, and the reactions are represented by the following equations:

$$
\begin{gathered}
2 \mathrm{SiO}^{-}+\mathrm{Pb}^{+2} \leftrightarrow(\mathrm{Si}-\mathrm{O})_{2}-\mathrm{Pb} \\
2 \mathrm{Si}-\mathrm{OH}+\mathrm{Pb}^{+2} \leftrightarrow(\mathrm{Si}-\mathrm{O})_{2}-\mathrm{Pb}+2 \mathrm{H}^{+2}
\end{gathered}
$$

Therefore, metal(loid) ions are completely removed at higher $\mathrm{pH}$ values. The effect of lowering the $\mathrm{pH}$ on the adsorption process is associated with the increase in the $\mathrm{H}^{+}$ions. These ions compete with the metal(loid) ions to bind to the negatively-charged sites (such as $\mathrm{SiO}^{-}$). If the number of negatively-charged sites available to form stable metal(loid) complexes is reduced, the adsorption rate of the metal(loid)s in the soil would also decrease. Another consequence of the increase in the $\mathrm{H}^{+}$ions is that the equilibrium represented by equation (2) shifts to the left side, which leads to a decrease in the rate of adsorption of the metal(loid) ions.

The adsorption of heavy metal(loid)s on oxides and humic compounds present in the soil follows the general trend of metal(loid) adsorption, i.e., higher adsorption at higher $\mathrm{pH}$. Moreover, in oxide minerals, $\mathrm{pH}$ is a primary variable determining the adsorption of cations and anions.

The adsorption of metal(loid)s is also affected by the competition between the amount of heavy metal(loid)s present and available for adsorption on the adsorbents. Zhang et al. (2016) [73] demonstrated experimentally that when two metals coexist ( $\mathrm{Cd}$ and $\mathrm{Hg}$ ), the adsorption capacity in activated carbon is higher for $\mathrm{Cd}(\mathrm{II})$ compared to $\mathrm{Hg}(\mathrm{II})$. However, this phenomenon was not observed if the concentrations of both metals are low as the adsorption sites available in the active carbon are, in such a case, sufficient for both metals. However, when the concentrations of both metals exceeded the adsorption capacity, $\mathrm{Cd}$ (II) was adsorbed preferentially over $\mathrm{Hg}(\mathrm{II})$. The authors stated that the higher adsorption capacity of $\mathrm{Cd}$ (II) compared to that of $\mathrm{Hg}(\mathrm{II})$ was due to a longer ionic radius [97 pm for $\mathrm{Cd}(\mathrm{II})$ and $110 \mathrm{pm}$ for $\mathrm{Hg}(\mathrm{II})$ ] corresponding to a shorter hydrated ionic radius, 
which leads to a greater affinity of the metal ions toward the activated sites of the adsorbent (activated carbon).

Moreover, Xie et al. (2018) [74] reported additional parameters that are also relevant in the competitive adsorption process. These authors studied the competitive adsorption of $\mathrm{Cu}(\mathrm{II})$ in the presence of $\mathrm{Zn}(\mathrm{II})$ and reported that $\mathrm{Cu}(\mathrm{II})$ exhibited a higher adsorption capacity for the following three reasons: 1 ) the greater electronegativity of $\mathrm{Cu}(\mathrm{II})$, which enhanced the ability of $\mathrm{Cu}(\mathrm{II})$ to adsorb the electrons of the ions; 2 ) the first-order hydrolysis constant of $\mathrm{Cu}(\mathrm{II})$, which is greater than that of $\mathrm{Zn}(\mathrm{II})$; 3) the greater ability of $\mathrm{Cu}(\mathrm{II})$ to form a covalent bond between the soil colloids and the metal ions.

\subsection{Heavy Metal(loid)s in Aquatic Ecosystems}

Heavy metal(loid)s are present naturally in aquatic ecosystems, although anthropic activities such as mining, navigation traffic, agricultural runoff, uncontrolled discharges of untreated industrial and domestic wastewater, etc., and floods contribute to increasing the levels of these elements in the aquatic environment. Moreover, $\mathrm{Hg}$ and $\mathrm{Pb}$ may enter aquatic environments through the atmosphere and as the fallout of insoluble precipitates, respectively [75].

In aquatic ecosystems, heavy metal(loid)s are partitioned among water, suspended solids, sediments, and biota (Figure 4), causing these to exist in various forms: a) as a free ion which is the form most toxic to living organisms; b) as an ion bound to different ligands (complex compounds); c) as the precipitated molecule of a compound, suspended in the liquid phase or adsorbed onto the surface of suspended or colloidal matter [76].

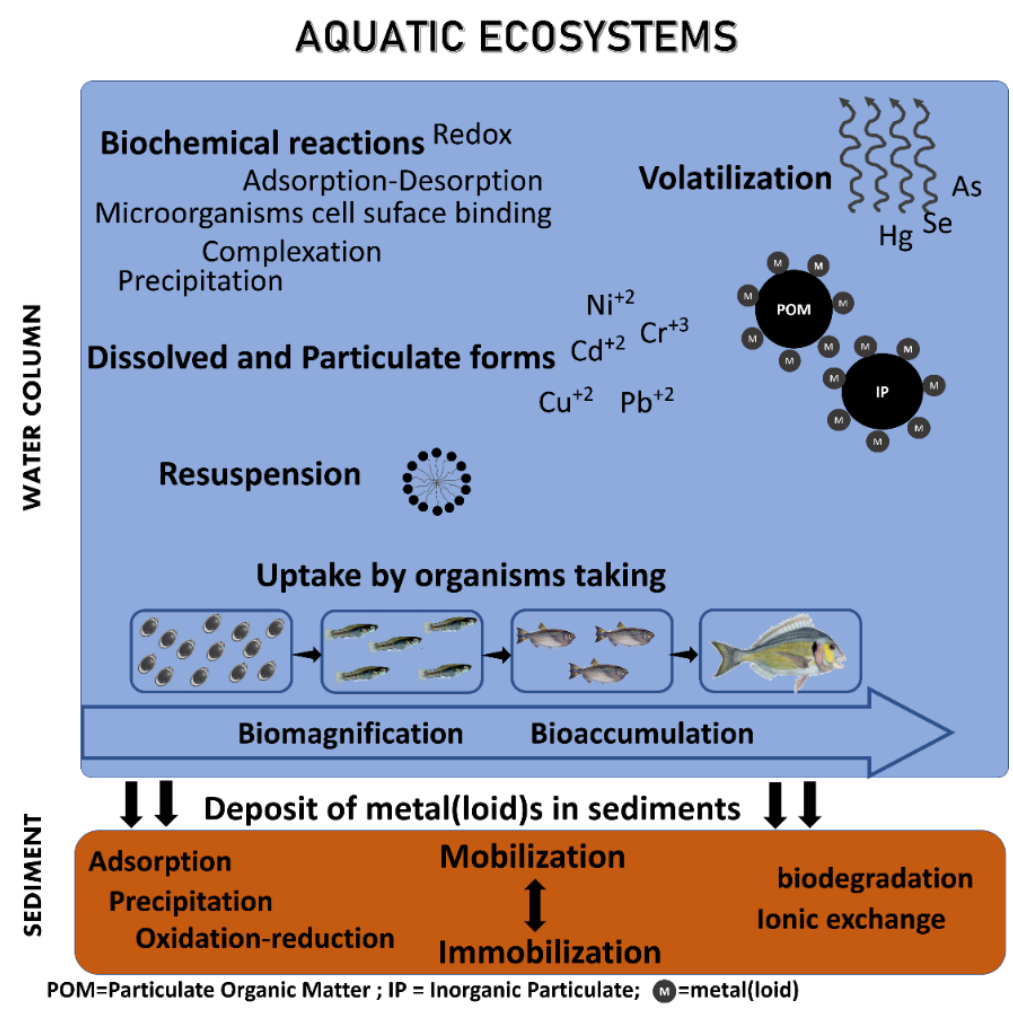

Figure 4 The heavy metal(loid)s in aquatic ecosystems. 
Sediments in the aquatic ecosystems are considered the main fate of heavy metal(loid)s as these elements exhibit extremely low solubility and are rapidly fixed on the solid material in the suspension. After the sinking process, the concentrations of these elements on sediments could be several orders of magnitude higher than those on the adjacent interstitial and overlying waters [77]. Once placed on sediments, the heavy metal(loid)s may be adsorbed onto several compartments, such as fine grains $(<63 \mu \mathrm{m})$, organic matter, and clay minerals, because of their large surface area per unit mass and their high cation-exchange capacity [78]. Therefore, sediments, in addition to serving as an accumulation repository, may also serve as a source of heavy metal(loid)s.

Moreover, the metal(loid)s dissolved in water are also absorbed by the fish and other aquatic organisms. Even when absorbed by organisms in small concentrations, the heavy metal(loid)s would undergo bioconcentration, i.e., their concentration in an organism becomes higher than that in water. Once inside the organism, the metal(loid)s exert their toxicity by producing adverse biological effects on the growth, metabolism, reproduction, or survival of these organisms.

The interaction between the microorganisms and the heavy metal(loid)s may be categorized into three different processes of metal(loid) distribution: intracellular interactions, cell-surface interactions, and extracellular interactions [79]. The first category involves the assimilation of heavy metal(loid)s by microbial cells. The most widely recognized intracellular interaction of microorganisms is the microbial methylation of $\mathrm{Hg}$, which leads to the volatilization and subsequent bioaccumulation of the lipid-soluble methylated form of $\mathrm{Hg}$ [80].

The second category is the cell-surface interactions, which are related to metal(loid) binding. For instance, algal surfaces contain functional groups such as carboxylic, amino, thio, hydroxo, and hydroxy-carboxylic groups, which may interact with metal(loid) ions by providing electronegative sites for metal(loid) binding [81]. The last category involves extracellular interaction between the metal(loid) and the biopolymers secreted by microorganisms (Extracellular Polymeric Substances, EPS), with the latter mainly comprising extracellular proteins, polysaccharides, and humus acid substances. Since these EPS contain abundant negatively-charged functional groups, these are efficient in adsorbing the metal(loid) ions through electrostatic attraction, complexation, ion exchange, surface precipitation, and other types of interactions [82]. The ions of these ecotoxicological elements $(\mathrm{Hg}, \mathrm{As}, \mathrm{Cr}, \mathrm{Pb}, \mathrm{Cd}, \mathrm{Ni}$, and $\mathrm{Zn}$ ) usually penetrate the cell through the same transport systems that use other physiologically important metal(loid) cations such as $\mathrm{Ca}, \mathrm{Mg}, \mathrm{Cu}$, Zn. etc. [83].

Therefore, depending on the process and the biological characteristics, an aquatic organism may be grouped into one of the two categories - regulators and accumulators. The first group governs metal(loid) accumulation and maintains the intracellular metal(loid) concentrations within a narrow range over a broad concentration range of external heavy metal(loid)s. The second group is capable of adopting a detoxification process in the presence of elevated metal(loid) levels even in noncontaminated environments.

As a consequence, heavy metal(loid)s might be lethal or harmful to the organism without killing it directly and rather by causing sublethal effects on an organism's physiological activities such as growth, metabolism, and reproduction [84].

Several aquatics ecosystems across the world have been impacted by human activity. TarrasWahlberg et al. (2011) [85] reported a fluvial ecosystem that had been highly impacted by the mining activities conducted in Portobelo-Zaruma. In this ecosystem, heavy metal(loid)s released due to the extraction works, rather than occurring in the soluble form (due to neutral-to-slightly alkaline 
water), were associated with suspended particles, river sediments, and biota, which suggested their potential bioavailability. These authors also reported elevated levels of $\mathrm{Hg}$ in the fish, which indicates that the methylation of $\mathrm{Hg}$ was occurring.

\section{Techniques for the Removal of Heavy Metal(loid)s}

\subsection{Removal of Heavy Metal(loid)s from Aqueous Effluents}

Traditionally, the heavy metal(loid)s present in industrial or domestic effluents were removed using different conventional techniques, such as chemical precipitation [86], ion flotation [87], ion exchange [88], coagulation/flocculation [89], adsorption [90], and electrochemical processes [91].

Most of these disposal processes have the advantage of low cost. Nevertheless, certain drawbacks exist, such as high energy requirements, production of a huge amount of toxic sludge that requires further treatment and proper disposal, and inadequate removal of the target element as evidenced by the non-attainment of high removal rates [92]. Moreover, during the last decades, environmental regulations across the world have become further stringent, demanding improvement in the quality of the treated effluent.

Therefore, to overcome these drawbacks of the conventional techniques and also to fulfill the regulatory requirements, novel technologies have been developed, which are based on the development of novel adsorbent compounds, the application of membrane separation, and other techniques [93] that are summarized in Figure 5.

Conventional
technologies
-Chemical
precipitation
-Adsortion using
activated carbon
- Ion flotation
- Ion exchange
- Coagulation and
Flocculation
- Electrochemical
process

Recent technologies
-Adsorption onto no-
conventional solids
- Chemical Hydrogels
- Nanoparticles and
nanotechnology
-Membrane filtration
(nano and
ultrafiltration)
-Biosorption
-Electrodialysis
-Photocatalysis

Figure 5 Technologies used for the removal of heavy metal(loid)s from aqueous effluents [92].

The techniques most studied in the literature, according to Qasem et al. (2021) [93], are chemical adsorption and membrane methods. However, these authors also stated that most of the reported studies were conducted with synthetic wastewater, which contains only one metal or a few metals. Therefore, although these novel technologies appear promising, further studies are required to assess and elucidate their feasibility as there remains a gap between the treatment of synthetic wastewater and the treatment of real wastewater.

Currently, these techniques are being improved with the development of novel adsorbents with better adsorption properties, novel types of membrane separation techniques such as ultrafiltration and nanofiltration, or even reverse osmosis. In the first group, use the use of the waste generated 
in a prior activity as a material to remove metals appears promising and sustainable. In 2020, Hernández-Cocoletzi et al. [94] used the hydroxyapatite derived from fish bones (skeletons of red snapper fish obtained from seafood restaurants, household waste, and fishmongers) as adsorbent to remove metal ions $\left(\mathrm{Ni}^{+2}, \mathrm{Cu}^{+2}\right.$, and $\left.\mathrm{Zn}^{+2}\right)$, achieving up to $95 \%$ elimination.

Furthermore, extensive research has been conducted on the treatment of aqueous effluents using agricultural residues or natural materials as low-cost adsorbent materials [95]. It has been revealed that after appropriate modifications (chemical or thermal), the agricultural residues exhibit a high capacity for metal removal. For instance, the use of natural adsorbents from coconut peels, neem leaves, and mango peels was demonstrated to achieve optimal levels of elimination [96]. This finding could be beneficial for the poor countries, which have limited access to high-cost advanced techniques, in deploying affordable treatment techniques for wastewater and also for the treatment of water meant for human consumption.

The membrane separation techniques (ultrafiltration and nanofiltration) have been demonstrated to achieve metal-removal percentages close to 100\% [97]. Ultrafiltration which uses membranes with a nominal pore size of 2-100 nm, has been demonstrated to achieve elimination efficiencies above $90 \%$ [98]. The main disadvantage of this technique is the fouling of the membrane, which has several adverse effects, such as flux reduction, increase in the transmembrane pressure, and membrane biodegradation [99]. The nanofiltration systems, which also use membranes with a nominal pore size of 1-2 $\mathrm{nm}$, require working pressures noticeably higher than those required in ultrafiltration, because of which the energy consumption is larger in nanofiltration than in ultrafiltration. The technique of reverse osmosis involves the use of membranes with a nominal pore diameter of $<1 \mathrm{~nm}$, which allows the efficient removal of most inorganic contaminants and the elimination of all polluting and undissolved ions, although extremely high working pressures are required. As a consequence, this membrane technology involves higher investment and operational costs [100]. Although the application of membrane-based techniques is expensive, it is important to highlight that wastewater could be utilized as a material resource for other purposes, thereby promoting a circular economy.

\subsection{Removal of Heavy Metal(loid)s from Contaminated Soils}

Soil pollution due to heavy metal(loid)s is a global concern. The concentrations of heavy metal(loid)s have increased dramatically in the last few decades, which has increased the environmental and human health-related risk. It is reported that over 10 million contaminated sites exist worldwide, with over $50 \%$ of these sites contaminated with heavy metal(loid)s [101].

The metal(loid)s released into the system become a threat to the environment and public health because of their persistence, non-biodegradability, and a tendency for bioaccumulation at different levels in the food chain. Moreover, polluted soil increases the risk of groundwater contamination. Therefore, the development and application of clean technologies are in high demand. Several technologies with promising results are emerging these days. Table 4 summarizes the most common techniques applied and the treatment methods these use.

Table 4 Techniques for the recovery of contaminated soil [102].

\begin{tabular}{lcc}
\hline Technique & Treatment & Application \\
\hline
\end{tabular}




\begin{tabular}{|c|c|c|c|}
\hline \multirow[t]{10}{*}{ Decontamination } & Physico- & Extraction & In-situ \\
\hline & Chemical & Washing & Ex-situ \\
\hline & & Flushing & In-situ \\
\hline & & Electrotechnical & In-situ \\
\hline & & Addition of amendments & In-situ \\
\hline & & Active permeable barriers & In-situ \\
\hline & Biological & Assisted biodegradation & In-situ \\
\hline & & $\begin{array}{l}\text { Biotransformation of Heavy } \\
\text { metals }\end{array}$ & In-situ \\
\hline & & Phytoremediation & In situ \\
\hline & Thermic & Thermic desorption & Ex-situ \\
\hline \multirow[t]{5}{*}{ Containment } & & Vertical barriers & In-situ \\
\hline & & Horizontal barriers & In-situ \\
\hline & & Dry soil barriers & In-situ \\
\hline & & Deep sealing & In-situ \\
\hline & & Hydraulic barriers & In-situ \\
\hline \multirow[t]{3}{*}{ Confinement } & & Physico-chemical stabilization & Ex-situ \\
\hline & & Injection of solidifiers & In-situ \\
\hline & & Vitrification & Ex-situ/In-situ \\
\hline
\end{tabular}

These soil treatment technologies are based on the following three principles: a) to contain the pollutant in the soil, b) to confine or isolate the pollutant by changing its physicochemical properties, and c) to reduce the concentration of the pollutant through different treatments. These three approaches may be categorized into in-situ or ex-situ types, depending on whether these are applied on-site or off-site, respectively.

Among the three groups of techniques listed in Table 4, two techniques are aimed at diminishing the flux of pollutants in the soil (containment and confinement), while the remaining one (decontamination) involves appropriate treatment of the pollutants to reduce their concentration. The selection of the technique is based on the soil properties, pollutant chemistry, and soilpollutant interaction. The physicochemical techniques of flushing and washing are applied widely to reduce contamination, although these generate secondary waste, which has to be treated further. Gusiatin et al. (2020) [103] analyzed the sources and characteristics of a few novel washing agents that could substitute ethylenediaminetetraacetic acid (EDTA) as the washing compound as the latter is toxic and requires treatment. Currently, the low-cost and environmentally friendly novel washing agents are being developed from geochemical sources, organic waste material, and compost.

The flushing technique is conducted in situ using an injection/recirculation system that pumps a washing solution through wells or using the infiltration processes. This enables the mobilization of the contaminants, which are removed from the soil by pumping the washing solution containing dissolved contaminants. The most widely used washing solutions are mineral acids (hydrochloric, sulfuric, and nitric acids), organic acids (oxalic acid and citric acid), synthetic organic chelating agents (EDTA, Diethylene triaminepentaacetic acid, DTPA, and Ethylene diaminodisuccinic acid, EDDS), and biosurfactants (saponin and rhamnolipids). In order to perform the washing technique, it is first necessary to separate the coarse soil particles from the and fine ones as the latter is the fraction containing the highest contamination values. Subsequently, these fine particles are treated with an 
appropriate washing solution containing water and chemicals followed by sonication or mechanical agitation.

In addition, biological methods are used to remediate soils, sediments, surface water, and even groundwater. In these methods, the pollutants are reduced due to the activity of microorganisms and/or plants and the associated rhizospheric microorganisms. These treatment methods are low in cost, and a few are even eco-friendly as these do not destroy the structure of the soil. For instance, Lofty and Mostafa (2014) [104] studied the use of different plant species in the extraction of Co and $\mathrm{Cr}$ from contaminated soils using two different wastewaters (sewage and industrial effluent). The results demonstrated that the shoots and roots of sunflower plants exhibited the highest $\mathrm{Co}$ and $\mathrm{Cr}$ uptake, suggesting that these approaches could play a crucial role in cleaning contaminated sites. It is important to highlight that these biological methods are environmentally friendly as they retain the physicochemical properties of the soil, such as soil structure. In addition, these methods are potentially cost-effective, although the time required to achieve the desired objective is longer.

In the case of applying these treatments to remove the metal(loid)s present in the aquatic matrix (wastewater, marine or freshwater, and groundwater), the results are varied. While several of these techniques, such as chemical precipitation, chemical coagulation and flocculation, electrochemical methods, membrane filtration, ion exchange, bioremediation, and adsorption process, have been successful, the adsorption process has demonstrated the highest efficiency, specificity, and costeffectiveness in removing heavy metal(loid)s from wastewater. An adsorbent agent used widely in wastewater treatment is activated carbon which has a greater surface area and affinity for heavy metal(loid)s [105]. However, the cost of this adsorbent is high, and its regeneration capacity is low, which limits its application. Nowadays, activated carbon is being replaced by other biomaterials derived from agricultural residues, such as rice husk, wheat residues, clay materials, etc., and industrial waste products, such as lignin, blast furnace sludge, slag, fly ash, red mud, etc. [96].

However, these techniques based on physicochemical treatments are either inefficient or expensive if the heavy metal(loid) concentration is under $100 \mathrm{mg} / \mathrm{L}$ [106]. Therefore, biological methods such as biosorption and phytoremediation emerge as attractive alternatives. Among the biological methods, filtration organisms such as mussels appear promising in cleaning small aquatic systems. In addition, the waste produced in this biological technique may be used in a second-step process involving anaerobic digestion for producing biogas. Therefore, it becomes possible to transform the soft tissues and shells into valuable materials that are rich in carbonates and oxides, such as the resulting calcined mussel shell, which has proved to be of value for soil amendment [107] that fosters the following circular economy principle: wastes serve as a resource for producing novel products.

\section{Conclusion and Scope for Further Research}

Although heavy metal(loid)s have origins in nature, human activities, such as rapid industrialization and technological development, have increased and mobilized these polluting elements in the environment. The generated heavy metal(loid)s adversely affect the soil, water, atmosphere, and even the health of animals and humans. This is preventable if industrial and technological development is conducted in parallel with the development and use of adequate treatment processes for the removal of the pollutants discharged into the environment. 
Although the currently existing technologies allow the removal of heavy metal(loid)s from soils and aquatic ecosystems, the applied treatment processes generate waste that requires appropriate treatment prior to discharge. Therefore, economic factors and the waste volume generated must be considered when selecting the most appropriate treatment technique.

Biological methods are a suitable option for cleaning and protecting the environment. The use of filtering organisms, such as bivalves, to remove contaminants and "clean" the water masses is beneficial as it reduces the higher costs involved in the conventional physicochemical treatment techniques while also generating residues that could later be utilized as raw materials for biogas production via anaerobic digestion of the soft tissues and shells to transform these into valuable materials. The use of wastes as raw materials for other processes is an important component of the circular economy, in which wastes serve as a resource for producing novel products.

Research has confirmed the efficiency and low cost of biological methods in the removal of heavy metal(loid)s. Therefore, further research should be conducted in this regard to extend the application of this technology, particularly to larger water bodies, such as lakes and/or rivers, for which the application of physicochemical methods is economically unfeasible. Achieving large-scale economic viability with a robust biological treatment process is essential to ensure its widespread application.

\section{Author Contributions}

Remedios Martinez-Guijarro conceived the review, carried out the literature search, and prepared the manuscript. Maria Pachés conceived the review, worked on the manuscript, and provided critical feedback. Daniel Aguado contributed to the final manuscript and provide critical feedback. Inmaculada Romero provided critical feedback.

\section{Competing Interests}

The authors have declared that no competing interests exist.

\section{References}

1. Upadhyay AK, Gupta KK, Sircar JK, Deb MK, Mundhara GL. Heavy metals in freshly deposited sediments of the river Subernarekha, India: An example of lithogenic and anthropogenic effects. Environ Geol. 2006; 50: 397-403.

2. Shah SB. Heavy metals in scleractinian corals. 1st ed. Cham: Springer; 2021.

3. Tchounwou PB, Yedjou CG, Patlolla AK, Sutton DJ. Heavy metal toxicity and the environment. In: Molecular, clinical and environmental toxicology. 1st ed. Basel: Springer; 2012.

4. Bánfalvi G. Cellular changes in mammalian cells induced by cadmium. In: Cellular effects of heavy metals. 1st ed. Dordrecht: Springer; 2011.

5. Tchounwou PB, Newsome C, Williams J, Glass K. Copper-induced cytotoxicity and transcriptional activation of stress genes in human liver carcinoma (HepG2) cells. Met lons Biol Med. 2008; 10: 285-290.

6. Grant R, Grant C. Grant and Hackh's chemical dictionary. 5th ed. New York: McGraw-Hill; 1987. 
7. Kushwaha A, Hans N, Kumar S, Rani R. A critical review on speciation, mobilization and toxicity of lead in soil-microbe-plant system and bioremediation strategies. Ecotoxicol Environ Saf. 2018; 147: 1035-1045.

8. Lyman WJ. Transport and transformation processes. In: Fundamentals of aquatic toxicology. 2nd ed. Boca Raton: CRC Press; 1995.

9. Duffus JH. " Heavy metals" a meaningless term? (IUPAC technical report). Pure Appl Chem. 2002; 74: 793-807.

10. Hodson ME. Heavy metals - geochemical bogey men? Environ Pollut. 2004; 129: 341-343.

11. Batley GE. "Heavy metal"-a useful term. Integr Environ Assess Manag. 2012; 8: 215.

12. Babula P, Adam V, Opatrilova R, Zehnalek J, Havel L, Kizek R. Uncommon heavy metals, metalloids and their plant toxicity: A review. In: Organic farming, pest control and remediation of soil pollutants. 1st ed. Dordrecht: Springer; 2009.

13. Kabata-Pendias A. Trace elements in soils and plants. 3rd ed. Boca Raton: CRC press; 2000.

14. Brady JP, Ayoko GA, Martens WN, Goonetilleke A. Development of a hybrid pollution index for heavy metals in marine and estuarine sediments. Environ Monit Assess. 2015; 187: 306.

15. Bradl HB. Sources and origins of heavy metals. Interface Sci Technol. 2005; 6: 1-27.

16. Burghelea $\mathrm{Cl}$, Dontsova K, Zaharescu DG, Maier RM, Huxman T, Amistadi MK, et al. Trace element mobilization during incipient bioweathering of four rock types. Geochim Cosmochim Acta. 2018; 234: 98-114.

17. Arunakumara KK, Walpola BC, Yoon MH. Current status of heavy metal contamination in Asia's rice lands. Rev Environ Sci Biotechnol. 2013; 12: 355-377.

18. Sharma RK, Agrawal M. Biological effects of heavy metals: An overview. J Environ Biol. 2005; 26: 301-313.

19. Khan MA, Khan S, Khan A, Alam M. Soil contamination with cadmium, consequences and remediation using organic amendments. Sci Total Environ. 2017; 601: 1591-1605.

20. Grimalt JO, Ferrer M, Macpherson E. The mine tailing accident in Aznalcollar. Sci Total Environ. 1999; 242: 3-11.

21. Morrow H. Cadmium and cadmium alloys. In: Kirk-Othmer encyclopedia of chemical technology. 5th ed. Hoboken: Wiley Blackwell; 2004.

22. Ma Q, Han L, Zhang J, Zhang Y, Lang Q, Li F, et al. Environmental risk assessment of metals in the volcanic soil of Changbai Mountain. Int J Environ Res Public Health. 2019; 16: 2047.

23. Ochota P, Prokopowicz A, Kośmider L, Choina M, Stebel A, Sobczak A. Heavy metals in moss samples exposed to the atmospheric dust after eruption of Eyjafjallajökull volcano. Med Srod. 2012; 15: 21-26.

24. Dixit R, Malaviya D, Pandiyan K, Singh UB, Sahu A, Shukla R, et al. Bioremediation of heavy metals from soil and aquatic environment: An overview of principles and criteria of fundamental processes. Sustainability. 2015; 7: 2189-2212.

25. Cempel M, Nikel GJ. Nickel: A review of its sources and environmental toxicology. Pol J Environ Stud. 2006; 15: 375-382.

26. Al-Khashman OA. Heavy metal distribution in dust, street dust and soils from the work place in karak industrial estate, Jordan. Atmos Environ. 2004; 38: 6803-6812.

27. López R, Hallat J, Castro A, Miras A, Burgos P. Heavy metal pollution in soils and urban-grown organic vegetables in the province of Sevilla, Spain. Biol Agric Hortic. 2019; 35: 219-237. 
28. Walraven N, Bakker M, Van Os B, Klaver G, Middelburg JJ, Davies G. Pollution and oral bioaccessibility of $\mathrm{Pb}$ in soils of villages and cities with a long habitation history. Int J Environ Res Public Health. 2016; 13: 221.

29. Centeno JA, Tchounwou PB, Patlolla AK, Mullick FG, Murakat L, Meza E, et al. Environmental pathology and health effects of arsenic poisoning: A critical review. In: Managing arsenic in the environment: From soil to human health. Handcover ed. Enfield: Science Pub Inc; 2006.

30. Mishra S, Chen S, Saratale GD, Saratale RG, Ferreira LF, Bilal M, et al. Reduction of hexavalent chromium by microbacterium paraoxydans isolated from tannery wastewater and characterization of its reduced products. J Water Process Eng. 2021; 39: 101748.

31. Tariq SR, Shah MH, Shaheen N, Khalique A, Manzoor S, Jaffar M. Multivariate analysis of trace metal levels in tannery effluents in relation to soil and water: A case study from Peshawar, Pakistan. J Environ Manage. 2006; 79: 20-29.

32. Sires J. A review of potential zinc and copper pollution sources in the kenai river watershed. [Internet]. Juneau: Alaska Department of Environmental Conservation; 2017. Available from: https://dec.alaska.gov/.

33. Chen $\mathrm{H}$, Teng $\mathrm{Y}$, Lu S, Wang Y, Wu J, Wang J. Source apportionment and health risk assessment of trace metals in surface soils of Beijing metropolitan, China. Chemosphere. 2016; 144: 10021011.

34. Cheng $\mathrm{H}$, Zhao C, Liu F, Yang K, Liu Y, Li M, et al. Mercury drop trend in urban soils in Beijing, China, since 1987. J Geochem Explor. 2013; 124: 195-202.

35. Agocs MM, Etzel RA, Parrish RG, Paschal DC, Campagna PR, Cohen DS, et al. Mercury exposure from interior latex paint. N Engl J Med. 1990; 323: 1096-1101.

36. Acosta JA, Faz A, Martinez-Martinez S. Identification of heavy metal sources by multivariable analysis in a typical Mediterranean city (SE Spain). Environ Monit Assess. 2010; 169: 519-530.

37. Franco-Uría A, López-Mateo C, Roca E, Fernández-Marcos ML. Source identification of heavy metals in pastureland by multivariate analysis in NW Spain. J Hazard Mater. 2009; 165: 10081015.

38. Kobayashi E, Suwazono Y, Dochi M, Honda R, Kido T. Influence of consumption of cadmiumpolluted rice or Jinzu River water on occurrence of renal tubular dysfunction and/or Itai-itai disease. Biol Trace Elem Res. 2009; 127: 257-268.

39. Keller AA, Adeleye AS, Conway JR, Garner KL, Zhao L, Cherr GN, et al. Comparative environmental fate and toxicity of copper nanomaterials. Nanolmpact. 2017; 7: 28-40.

40. Bretzel F, Calderisi M, Scatena M, Pini R. Soil quality is key for planning and managing urban allotments intended for the sustainable production of home-consumption vegetables. Environ Sci Pollut Res. 2016; 23: 17753-17760.

41. Fishel FM. Pesticide toxicity profile: Copper-based pesticides [Internet]. Gainesville: UF/IFAS Electronic Data Information System; 2005. Available from: https://www.mendeley.com/catalogue/342b6b28-095b-319f-a4da-00567cb611e8/.

42. Park JH, Bolan NS. Potential value of biowastes in the remediation of toxic metal (loid)contaminated soils. In: Soil and groundwater remediation technologies. 1st ed. Boca Raton: CRC Press; 2020.

43. Hejna M, Moscatelli A, Onelli E, Baldi A, Pilu S, Rossi L. Evaluation of concentration of heavy metals in animal rearing system. Ital J Anim Sci. 2019; 18: 1372-1384. 
44. Cai L, Xu Z, Bao P, He M, Dou L, Chen L, et al. Multivariate and geostatistical analyses of the spatial distribution and source of arsenic and heavy metals in the agricultural soils in Shunde, Southeast China. J Geochem Explor. 2015; 148: 189-195.

45. Marques AP, Rangel AO, Castro PM. Remediation of heavy metal contaminated soils: Phytoremediation as a potentially promising clean-up technology. Crit Rev Env Sci Tec. 2009; 39: 622-654.

46. Ross SM. Sources and forms of potentially toxic metals in soil-plant systems. In: Toxic metals in soil-plant systems. 1st ed. New York: Wiley; 1994.

47. Finley BD, Swartzendruber PC, Jaffe DA. Particulate mercury emissions in regional wildfire plumes observed at the Mount Bachelor Observatory. Atmos Environ. 2009; 43: 6074-6083.

48. Naderizadeh Z, Khademi H, Ayoubi S. Biomonitoring of atmospheric heavy metals pollution using dust deposited on date palm leaves in southwestern Iran. Atmosfera. 2016; 29: 141-155.

49. Salomons W, Bayne BL, Duursma EK, Förstner U. Pollution of the North Sea - an Assessment. 1st ed. Berlin, Heidelberg: Springer; 1998.

50. Peirson DH, Cawse PA, Salmon L, Cambray RS. Trace elements in the atmospheric environment. Nature. 1973; 241: 252-256.

51. Van Malderen $\mathrm{H}$, Hoornaert S, Van Grieken R. Identification of individual aerosol particles containing $\mathrm{Cr}, \mathrm{Pb}$, and $\mathrm{Zn}$ above the North Sea. Environ Sci Technol. 1996; 30: 489-498.

52. Adriano DC, Wenzel WW, Vangronsveld J, Bolan NS. Role of assisted natural remediation in environmental cleanup. Geoderma. 2004; 122: 121-142.

53. Cao $X$, Tan $C$, Wu L, Luo $Y$, He $Q$, Liang $Y$, et al. Atmospheric deposition of cadmium in an urbanized region and the effect of simulated wet precipitation on the uptake performance of rice. Sci Total Environ. 2020; 700: 134513.

54. Krishna AK, Govil PK. Soil contamination due to heavy metals from an industrial area of Surat, Gujarat, Western India. Environ Monit Assess. 2007; 124: 263-275.

55. Draszawka-Bolzan B. Heavy metals in soils. World News Nat Sci. 2015; 2: 20-37.

56. Tangahu BV, Abdullah SR, Basri H, Idris M, Anuar N, Mukhlisin M. A review on heavy metals (As, $\mathrm{Pb}$, and $\mathrm{Hg}$ ) uptake by plants through phytoremediation. Int J Chem Eng. 2011; 2011: 939161.

57. McLean JE, Bledsoe BE. Behaviour of metals in soils [Internet]. Washington DC: Environmental Protection Agency; 2021. Available from: https://www.epa.gov/remedytech/behavior-metalssoils.

58. Calace N, Deriu D, Petronio BM, Pietroletti M. Adsorption isotherms and breakthrough curves to study how humic acids influence heavy metal-soil interactions. Water Air Soil Pollut. 2009; 204: 373-383.

59. Benjamin $\mathrm{MM}$, Leckie JO. Effects of complexation by $\mathrm{Cl}, \mathrm{SO}_{4}$, and $\mathrm{S}_{2} \mathrm{O}_{3}$ on adsorption behavior of Cd on oxide surfaces. Environ Sci Technol. 1982; 16: 162-170.

60. Caporale AG, Violante $A$. Chemical processes affecting the mobility of heavy metals and metalloids in soil environments. Curr Pollution Rep. 2016; 2: 15-27.

61. Kunhikrishnan A, Seshadri B, Choppala G, Shankar S, Thangarajan R, Bolan N. Redox reactions of heavy metal (loid) $s$ in soils and sediments in relation to bioavailability and remediation. In: Trace elements in waterlogged soils and sediments. 1st ed. Boca Raton: CRC Press; 2016.

62. Mahimairaja S, Bolan NS, Adriano DC, Robinson B. Arsenic contamination and its risk management in complex environmental settings. Adv Agron. 2005; 86: 1-82. 
63. Ross SM. Retention, transformation and mobility of toxic metals in soils. In: Toxic metals in soilplant systems. 1st ed. New York: Wiley; 1994.

64. Chuan MC, Shu GY, Liu JC. Solubility of heavy metals in a contaminated soil: Effects of redox potential and pH. Water Air Soil Pollut. 1996; 90: 543-556.

65. Patrick WH, Gambrell RP, Faulkner SP. Redox measurements of soils. In: Methods of soil analysis, part 3: Chemical methods. 1st ed. Madison: Soil Science Society of America, Inc and American Society of Agronomy, Inc; 1996.

66. Wiatrowski HA, Ward PM, Barkay T. Novel reduction of mercury (II) by mercury-sensitive dissimilatory metal reducing bacteria. Environ Sci Technol. 2006; 40: 6690-6696.

67. Bachate SP, Khapare RM, Kodam KM. Oxidation of arsenite by two $\beta$-proteobacteria isolated from soil. Appl Microbiol Biotechnol. 2012; 93: 2135-2145.

68. Roane TM, Pepper IL, Gentry TJ. Microorganisms and metal pollutants. In: Environmental microbiology. 3rd ed. Cambridge: Academic Press; 2015.

69. Yin XX, Chen J, Qin J, Sun GX, Rosen BP, Zhu YG. Biotransformation and volatilization of arsenic by three photosynthetic cyanobacteria. Plant Physiol. 2011; 156: 1631-1638.

70. Okuno $T$, Kubota $T$, Kuroda $T$, Ueno $H$, Nakamuro K. Contribution of enzymic $\alpha, \gamma$-elimination reaction in detoxification pathway of selenomethionine in mouse liver. Toxicol Appl Pharmacol. 2001; 176: 18-23.

71. Kerndorff H, Schnitzer M. Sorption of metals on humic acid. Geochim Cosmochim. Acta. 1980; 44: 1701-1708.

72. Omar $\mathrm{W}, \mathrm{Al}-$ Itawi $\mathrm{H}$. Removal of $\mathrm{Pb}+2$ ions from aqueous solutions by adsorption on kaolinite clay. Am J Appl Sci. 2007; 4: 502-507.

73. Zhang X, Hao Y, Wang X, Chen Z, Li C. Competitive adsorption of cadmium (II) and mercury (II) ions from aqueous solutions by activated carbon from Xanthoceras sorbifolia Bunge hull. J Chem. 2016; 2016; 4326351.

74. Xie S, Wen Z, Zhan H, Jin M. An experimental study on the adsorption and desorption of Cu (II) in silty clay. Geofluids. 2018; 2018: 3610921.

75. Pachana K, Wattanakornsiri A, Nanuam J. Heavy metal transport and fate in the environmental compartments. NU Int J Sci. 2010; 7: 1-11.

76. Namieśnik J, Rabajczyk A. The speciation and physico-chemical forms of metals in surface waters and sediments. Chem Speciat Bioavailab. 2010; 22: 1-24.

77. Wang WX. Interactions of trace metals and different marine food chains. Mar Ecol Progress Series. 2002; 243: 295-309.

78. Larsen O, Davison W, Vamvakopoulos K, Møhlenberg F. Fine sediment particles. In: Sediment dynamics and pollutant mobility in rivers. 1st ed. Berlin and Heidelberg: Springer; 2007.

79. Ford T, Maki J, Mitchell R. Metal-microbe interactions. In: Bioextraction and biodeterioration of metals. 1st ed. Cambridge: Cambridge University Press; 1995.

80. Bustamante P, Lahaye V, Durnez C, Churlaud C, Caurant F. Total and organic Hg concentrations in cephalopods from the North Eastern Atlantic waters: Influence of geographical origin and feeding ecology. Sci Total Environ. 2006; 368: 585-596.

81. Cao $X, \operatorname{Tan} C$, Wu L, Luo $Y$, He $Q$, Liang $Y$, et al. Atmospheric deposition of cadmium in an urbanized region and the effect of simulated wet precipitation on the uptake performance of rice. Sci Total Environ. 2020; 700: 134513. 
82. Yan P, Xia JS, Chen YP, Liu ZP, Guo JS, Shen Y, et al. Thermodynamics of binding interactions between extracellular polymeric substances and heavy metals by isothermal titration microcalorimetry. Bioresour Technol. 2017; 232: 354-363.

83. Castañé PM, Topalián ML, Cordero RR, Salibián A. Influencia de la especiación de los metales pesados en medio acuático como determinante de su toxicidad. Rev de Toxicol. 2003; 20: 1318.

84. Wright DA, Welbourn P. Environmental toxicology. 1st ed. Cambridge: Cambridge University Press; 2002.

85. Tarras-Wahlberg NH, Flachier A, Lane SN, Sangfors O. Environmental impacts and metal exposure of aquatic ecosystems in rivers contaminated by small scale gold mining: The Puyango river basin, southern Ecuador. Sci Total Environ. 2001; 278: 239-261.

86. Benalia MC, Youcef L, Bouaziz MG, Achour S, Menasra H. Removal of heavy metals from industrial wastewater by chemical precipitation: Mechanisms and sludge characterization. Arab J Sci Eng. 2021. DOI: 10.1007/s13369-021-05525-7.

87. Hoseinian FS, Rezai B, Kowsari E, Chinnappan A, Ramakrishna S. Synthesis and characterization of a novel nanocollector for the removal of nickel ions from synthetic wastewater using ion flotation. Sep Purif Technol. 2020; 240: 116639.

88. Bashir A, Malik LA, Ahad S, Manzoor T, Bhat MA, Dar GN, et al. Removal of heavy metal ions from aqueous system by ion-exchange and biosorption methods. Environ Chem Lett. 2019; 17: 729-754.

89. Sun Y, Zhou S, Pan SY, Zhu S, Yu Y, Zheng H. Performance evaluation and optimization of flocculation process for removing heavy metal. Chem Eng J. 2020; 385: 123911.

90. Burakov AE, Galunin EV, Burakova IV, Kucherova AE, Agarwal S, Tkachev AG, et al. Adsorption of heavy metals on conventional and nanostructured materials for wastewater treatment purposes: A review. Ecotox Environ Safe. 2018; 148: 702-712.

91. Muddemann T, Haupt D, Sievers M, Kunz U. Electrochemical reactors for wastewater treatment. Chem Bio Eng Rev. 2019; 6: 142-156.

92. Shrestha R, Ban S, Devkota S, Sharma S, Joshi R, Tiwari AP, et al. Technological trends in heavy metals removal from industrial wastewater: A review. J Environ Chem Eng. 2021; 9: 105688.

93. Qasem NA, Mohammed RH, Lawal DU. Removal of heavy metal ions from wastewater: A comprehensive and critical review. NPJ Clean Water. 2021; 4: 36.

94. Hernández-Cocoletzi H, Salinas RA, Águila-Almanza E, Rubio-Rosas E, Chai WS, Chew KW, et al. Natural hydroxyapatite from fishbone waste for the rapid adsorption of heavy metals of aqueous effluent. Environ Technol Innov. 2020; 20: 101109.

95. Joseph L, Jun BM, Flora JR, Park CM, Yoon Y. Removal of heavy metals from water sources in the developing world using low-cost materials: A review. Chemosphere. 2019; 229: 142-159.

96. Abdulraheem FS, Al-Khafaji ZS, Hashim KS, Muradov M, Kot P, Shubbar AA. Natural filtration unit for removal of heavy metals from water. IOP Conf Ser: Mater Sci Eng. 2020; 888: 012034.

97. Garba MD, Usman M, Mazumder MA, Al-Ahmed A. Complexing agents for metal removal using ultrafiltration membranes: A review. Environ Chem Lett. 2019; 17: 1195-1208.

98. Wang J, Chen C. The current status of heavy metal pollution and treatment technology development in China. Environ Technol Rev. 2015; 4: 39-53.

99. Kurniawan TA, Chan GY, Lo WH, Babel S. Physico-chemical treatment techniques for wastewater laden with heavy metals. Chem Eng J. 2006; 118: 83-98. 
100.Atab MS, Smallbone AJ, Roskilly AP. An operational and economic study of a reverse osmosis desalination system for potable water and land irrigation. Desalination. 2016; 397: 174-184.

101. Khalid S, Shahid M, Niazi NK, Murtaza B, Bibi I, Dumat C. A comparison of technologies for remediation of heavy metal contaminated soils. J Geochem Explor. 2017; 182: 247-268.

102. Ortiz Bernard I, Sanz García J, Dorado Valiño M, Villar Fernández S. Técnicas de recuperación de suelos contaminados [Internet]. Madrid: Community of Madrid; 2007. Available from: https://www.madrimasd.org/cultura-cientifica/ciencia-cultura/ensayo/tecnicas-recuperacionsuelos-contaminados.

103.Gusiatin ZM, Kulikowska D, Klik B. New-generation washing agents in remediation of metalpolluted soils and methods for washing effluent treatment: A review. Int J Environ Res Public Health. 2020; 17: 6220.

104.Lotfy SM, Mostafa AZ. Phytoremediation of contaminated soil with cobalt and chromium. J Geochem Explor. 2014; 144: 367-373.

105. Kaveeshwar AR, Kumar PS, Revellame ED, Gang DD, Zappi ME, Subramaniam R. Adsorption properties and mechanism of barium (II) and strontium (II) removal from fracking wastewater using pecan shell based activated carbon. J Clean Prod. 2018; 193: 1-3.

106. Ahluwalia SS, Goyal D. Microbial and plant derived biomass for removal of heavy metals from wastewater. Bioresour Technol. 2007; 98: 2243-2257.

107.Álvarez E, Fernández-Sanjurjo MJ, Seco N, Núñez A. Use of mussel shells as a soil amendment: Effects on bulk and rhizosphere soil and pasture production. Pedosphere. 2012; 22: 152-164.

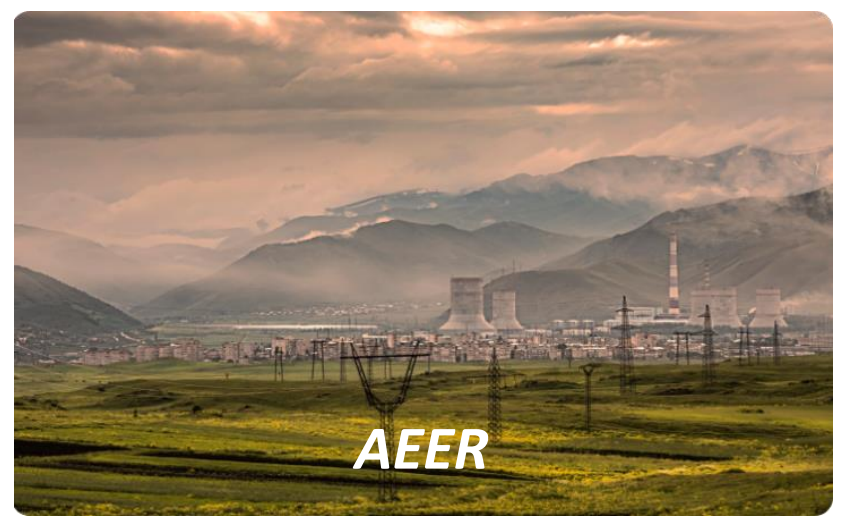

Enjoy AEER by:

1. Submitting a manuscript

2. Joining in volunteer reviewer bank

3. Joining Editorial Board

4. Guest editing a special issue

For more details, please visit:

http://www.lidsen.com/journals/aeer 